\title{
What's in a Duty? EU Identification of Non-cooperating Port States and Their Prescriptive Responses
}

\author{
Arron N. Honniball \\ PhD Candidate, Utrecht University, Utrecht, The Netherlands
}

\begin{abstract}
Council Regulation (EC) No $1005 / 2008$ provides that a third country may be identified and subject to measures if it fails "to discharge the duties incumbent upon it under international law as flag, port, coastal or market state, to take action to prevent deter and eliminate IUU fishing". In assessing the promise or limits of this unilateral listing mechanism, the question arises as to what influence, if any, it has had on third-country legislation. This article uses a case study on port state duties, demonstrating the use and impact of the unilaterally defined port state duties and their implementation in EU practice. The latter part addresses trends in the prescriptive responses of port states, including whether the EU listing process was a contributing factor to legislative reform. Prescriptive trends highlighted are the implementation of generally accepted treaty-based port state measures, followed by three examples of expansion into port state offences.
\end{abstract}

\section{Keywords}

jurisdiction - duty - port state - illegal, unreported and unregulated (IUU) fishing European Union (EU)

\section{Introduction}

Combatting illegal, unreported and unregulated (IUU) fishing, regardless of where it occurs, is a central tenet of the European Union's (EU) Common 
Fisheries Policy. ${ }^{1}$ This is not just a matter of promoting conservation and management of marine living resources. It is equally a mechanism to level the playing field between EU operators and third-country (non-EU) operators. A third-country vessel will gain an 'unfair advantage' by operating under the legislation of a state perceived by the $\mathrm{EU}$ to be acting inconsistently with its international obligations to prevent, deter and eliminate IUU fishing.

To address this, the EU flexes its market and port state muscles through the non-cooperating third-country identification procedure of Council Regulation (EC) No 1005/2008 (IUU Regulation). Thus, a state may be identified and subject to EU measures if it fails "to discharge the duties incumbent upon it under international law as flag, port, coastal or market state, to take action to prevent deter and eliminate IUU fishing". ${ }^{2}$ These duties require states to, inter alia, take 'appropriate measures' to ensure compliance by vessels and nationals with applicable fisheries conservation and management measures (CMMs). ${ }^{3}$ The 'appropriate measures' in a state's capacity as flag, port, coastal or market state depend on its jurisdictional rights and obligations under international fisheries law for each capacity.

The present article selects the implementation of port state duties as its case study. ${ }^{4}$ Port state measures are a cost-effective tool to ensure that visiting foreign vessels comply with CMMs. They are also the focal point of the first

1 The research that resulted in this publication was funded by the European Research Council under the Starting Grant Scheme (Proposal 336230 - UnIJURIS). The author wishes to thank participants in the External Challenges for the Common Fisheries Policy Symposium (Edinburgh, 11 May 2018) for their perceptive discussion. The author also wishes to thank the editors of this special issue for their comments that have greatly benefited the text. European Commission (Commission), 'On the application of Council Regulation (EC) No 1005/2008 establishing a Community system to prevent, deter and eliminate illegal, unreported and unregulated fishing' (Communication from the Commission to the European Parliament and the Council) $\operatorname{com}(2015) 480$ final, 1 October 2015, at pt. 2.2, a toolkit for global change; Council Regulation (EC) No. 1005/2008 of 29 September 2008 establishing a Community system to prevent, deter and eliminate illegal, unreported and unregulated fishing, amending Regulations (EEC) No. 2847/93, (EC) No. 1936/2001 and (EC) No. 601/2004 and repealing Regulations (EC) No. 1093/94 and (EC) No. 1447/1999 [2008] OJ L286/1, Chapter vi global policy objectives.

2 EC No. 1005/2008 (n 1), Article 31(3).

3 EC No. 1005/2008 (n 1), Recital [30].

4 See more broadly, Commission, 'Overview of existing procedures as regards third countries', July 2018, available at https://ec.europa.eu/fisheries/sites/fisheries/files/illegal-fishingoverview-of-existing-procedures-third-countries_en.pdf; accessed 29 November 2018. E.g., flag states, C Elvestad and I Kvalvik, 'Implementing the EU-IUU Regulation: Enhancing Flag State Performance through Trade Measures' (2015) 46(3) Ocean Development \& International Law 241-255. 
legally binding treaty at the global level to target IUU fishing, the Port State Measures Agreement (PSMA). ${ }^{5}$ However, to remain effective and avoid the development of ports of non-compliance, ${ }^{6}$ all relevant port states should implement measures to deny port access and port services to vessels involved in IUU fishing activities, as well as vessels possessing fish that result from IUU fishing activities.

This article begins by introducing the non-cooperating third-country identification procedure and its context in the IUU Regulation. This is followed by an analysis of the extent to which port state duties feature in EU practice under the IUU Regulation. Such an analysis entails a brief review of a port state's duty under international law and how this is interpreted and applied by the EU to notify, identify, and list non-EU port states.

In assessing the promise or limits of this unilateral listing mechanism, the question arises as to what influence, if any, it has had on third-country legislation. By incentivising reform and "mind-set change", the EU aims to contribute to "better oceans governance globally". ${ }^{7}$ The objectives of the EU will only be met if third countries undertake legislative reform. This article therefore explains how non-EU port states have amended their national legislation to address EU concerns. Non-EU port states are implementing treaty-based minimum port state standards, regardless of whether they are a contracting party, and prescribing port state offences which go beyond any port state duties under international law.

There is not always a clear causal link between the EU listing mechanism and subsequent legislative changes in third countries. Official statements and documentation do however suggest that the EU listing mechanism is one of the contributing factors to legislative reform. After discussing these and other potentially influential factors, the conclusion places the findings in the context of the international law of jurisdiction and, for the EU, in its broader external oceans policy.

5 Agreement on Port State Measures to Prevent, Deter and Eliminate Illegal, Unreported and Unregulated Fishing (Rome, 22 November 2009, in force 5 June 2016) (PSMA), UNTS No 54133.

6 Sometimes referred to as ports of convenience.

7 Commission, 'The EU and FAO closing the door to illegal fish' (2016) 72 European Maritime Affairs \& Fisheries 4-5, at p. 4. E.g., flags of convenience or non-compliance present threats to global and EU interests; Commission, 'Community Action Plan for the Eradication of Illegal, Unreported and Unregulated Fishing' (Communication) СОм (2002) 180 final, 28 May 2002, at pp. 3-4, 10. 


\section{The EU IUU Regulation and Non-cooperating Third Countries in Fighting IUU Fishing}

IUU fishing is a broad term referring to activities that either violate, or are inconsistent with, applicable cMMs. Where no cMMs are applicable, unregulated fishing encompasses activities inconsistent with a state's conservation obligations. ${ }^{8}$ IUU fishing undermines efforts at the global, regional and national level to manage fisheries, leading to well-discussed environmental, economic and societal threats. 9

For the EU's external Common Fisheries Policy, the IUU Regulation is the core instrument to prevent, deter and eliminate IUU fishing. The IUU Regulation provides a multitude of tools to combat IUU fishing globally, including cases where only foreign marine ecosystems are threatened. ${ }^{10}$ These tools include, amongst others, port state measures, a catch certification scheme, state of nationality measures and a Community IUU vessel list.

Chapter VI of the IUU Regulation contains the key provisions that respond to what the EU perceives as a failure by third countries to address IUU fishing in line with their international responsibilities. The EU may identify a noncooperating third country and adopt numerous measures to influence that state. ${ }^{11}$ In general, a non-cooperating third country is one which has failed "to discharge the duties incumbent upon it under international law as flag, port, coastal or market state, to take action to prevent deter and eliminate IUU fishing". ${ }^{12}$ This test will be elaborated below for port states.

The non-cooperating third-country identification procedure is not unique in international law. For example, comparable trade-restrictive measures are imposed through the implementation of procedures set by Regional Fisheries Management Organisations/Arrangements (RFMO/As) to identify flag states of non-compliance, including non-cooperating non-contracting parties to

FAO, International Plan of Action to Prevent, Deter and Eliminate Illegal, Unreported and Unregulated Fishing (IPOA-IUU) (FAO, Rome, 2001), available at http://www.fao.org/3/ay1224e.pdf; accessed 30 July 2018, at para. 3; EC No. 1005/2008 (n 1), Article 2; JT Theilen, 'What's in a Name? The Illegality of Illegal, Unreported and Unregulated Fishing' (2013) 28(3) The International Journal of Marine and Coastal Law 533-550.

European Parliament, 'Resolution of 17 November 2011 On Combating Illegal Fishing at the Global Level - The Role of the EU', OJ C 153E, 31/5/2013, p 148-157, 17 November 2011, at paras. B, 2; EC No. 1005/2008 (n 1), Recital [3]. PSMA (n 5), Preamble. Commission Press Release, 'Commission warns Vietnam over insufficient action to fight illegal fishing' (IP/17/4064) 23 October 2017, available at http://europa.eu/rapid/pressrelease_IP-17-4064_en.htm; accessed 29 July 2018.

11 EC No. $1005 / 2008$ (n 1$)$, Article 38.

12 Ibid., Article 31(3). 
an RFMO/A.13 A similar mechanism under the EU's Non-Sustainable Fishing Regulation also allows EU measures vis-à-vis states identified as allowing nonsustainable fishing of a "stock of common interest". 14

The identification procedure involves five stages. First, a bilateral dialogue occurs. In most cases this and assistance appear sufficient to improve third-country governance, with the EU quoting over 50 successful outcomes. ${ }^{15}$ Where third countries needed to undertake legislative or administrative reform, the EU reports a more conservative 15 states as having adopted the necessary reform. ${ }^{16}$ However, by including third-country alignment without EU engagement, this could include up to 91 states complying "with international and EU standards" to avoid EU trade-restrictive measures. ${ }^{17}$

If discussions fail to reach a resolution, the European Commission (Commission) will issue a pre-identification notification ('yellow card'). ${ }^{18}$ When a notified state introduces sufficient reform, or refutes the pre-identification, the pre-identification is revoked ('green card').

Alternatively, the Commission may identify the state as a non-cooperating third country ('red card: step I'). ${ }^{19}$ Upon 'identification' by the Commission, fish products caught by vessels flagged to the identified third country shall be refused importation into the Community, and possibly be confiscated by EU

13 G Hosch, Trade Measures to Combat IUU Fishing: Comparative Analysis of Unilateral and Multilateral Approaches (International Centre for Trade and Sustainable Development (ICTSD), Geneva, 2016), at p. 15; M Tsamenyi, M Palma, B Milligan and K Mfodwo, 'The European Council Regulation on Illegal, Unreported and Unregulated Fishing: An International Fisheries Law Perspective' (2010) 25(1) The International Journal of Marine and Coastal Law 5-31, 30.

14 Regulation (EU) No 1026/2012 of the European Parliament and of the Council of 25 October 2012 on certain measures for the purpose of the conservation of fish stocks in relation to countries allowing non-sustainable fishing [2012] OJ L316/34, Articles 1, 2(a), 4(1). Commission Implementing Regulation (EU) No 793/2013 of 20 August 2013 establishing measures in respect of the Faeroe Islands to ensure the conservation of the AtlantoScandian herring stock [2013] OJ L223/1, Articles 4-6. M Vatsov, 'The EU's failed attempt to innovate with Regulation 1026/2012' (2017) 84 Marine Policy 300-305.

15 Commission, 'The EU leveraging global change for the good governance of fisheries' (2015) 67 European Maritime Affairs \& Fisheries 6-7, at p. 7. However, Commission Press Release, IP/17/4064 (n 1), still claims 50 states, suggesting this is a rounded number rather than an accurate summary.

16 Commission, $\operatorname{COM}(2015) 480$ final (n 1), at p. 5 .

17 E.g., through shared values or to avoid the possibility of EU measures; Commission, 'The EU leveraging global change' (n 15), at p. 7 .

18 EC No. 1005/2008 (n 1), Article 32(1).

19 Ibid., Article 31(1). 
Member States. ${ }^{20}$ The Council of the European Union (Council) will then decide on addition to the list of non-cooperating third countries ('red card: step II'). ${ }^{21}$ 'Listing' by the Council will trigger the application of Article 38 of the IUU Regulation, which results in various actions by the Commission and by EU Member States as flag state, market state, and state of nationality. ${ }^{22}$ Port state measures are not explicitly mentioned in Article 38 , but will result from the invalidity of catch certificates issued by a listed third country. ${ }^{23}$ This is because the practical effect of invalid catch documentation is the denial of port entry for vessels carrying those fishery products. ${ }^{24}$ Identification and listing are therefore "of last resort and will only be taken after numerous consultations with the country". 25

Listed third countries will only be delisted when there has been a demonstrable rectification of the issues identified by the Commission, considering "concrete measures capable of achieving a lasting improvement" ('green card') ${ }^{26}$ This decision is again taken by the Council following a proposal by the Commission.

Finally, it is worth noting that other IUU Regulation measures may address the inadequate exercise of jurisdiction by third countries. Measures against IUU fishing vessels or against products that result from IUU fishing may, in part, address "deficiencies" in third countries' flag state jurisdiction. ${ }^{27}$ Furthermore, temporary emergency measures may be adopted when "there is evidence that the measures adopted by a third country undermine the conservation and management measures adopted by a regional fisheries management organisation". ${ }^{28}$ The EU has not yet implemented (or considered it necessary to implement) emergency measures, but these can include

$20 \quad$ Ibid., Articles 18(1)(g); 18(3). E.g. Commission Implementing Decision 2014/715/EU (Index Table), at para. 69 (Sri Lanka).

21 EC No. 1005/2008 (n 1), Article 33(1).

22 Ibid., Article 38. Implementation; e.g., The Sea Fisheries (Miscellaneous Amendments) Regulations 2018, S.I. No. 643 of 2018, 22 May 2018, Article 5(3) (UK).

23 EC No. 1005/2008 (n 1), Article 38(1).

24 Ibid., Articles 6(2), 7(1).

25 Commission, 'Handbook on the Practical Application of Council Regulation (EC) No. 1005/2008 of 29 September 2008 Establishing a Community System to Prevent, Deter and Eliminate Illegal, Unreported and Unregulated Fishing (The IUU Regulation)', Mare A4/ PS D(2009) A/1288o, October 2009, at p. 65.

26 EC No. 1005/2008 (n 1), Article 34(1).

27 Ibid., Recital [27], Chapter v; Commission Regulation (EC) No 1010/2009 of 22 October 2009 laying down detailed rules for the implementation of Council Regulation (EC) No 1005/2008 establishing a Community system to prevent, deter and eliminate illegal, unreported and unregulated fishing [2009] OJ L280/5, Articles 4(s), 31(n). 
flag, port, market and coastal state measures by EU Member States with immediate effect. ${ }^{29}$

\section{Identifying Non-cooperating Port States in Fighting IU U Fishing}

Implementation of the non-cooperating third-country identification procedure in the context of port state duties can be found in the table annexed to this article, Index Table: EU Practice On Third Countries Failure to Discharge Port State Duties (Index Table). This practice is demonstrative of two key findings. First, a port state's duty under international law is broadly interpreted and applied by the EU. Second, the procedure allows for considerable unilateralism in its application. Although not prohibited by international law, ${ }^{30}$ such unilateralism is generally discouraged by global instruments, ${ }^{31}$ and has been the subject of criticism when exercised by the EU. ${ }^{32}$ The formal process nonetheless consistently includes references to a third country's inadequate port state measures to combat IUU fishing.

\section{A Port State's Duty under International Law as Interpreted by the EU}

Identifying a third country as having failed to discharge its port state duties presupposes the existence of port state duties under international law. Port state duties in global instruments have been in a state of flux and evolution since the Fish Stocks Agreement (UNFSA) recognised that a port state "has the right and the duty to take measures, in accordance with international law, to promote the effectiveness of subregional, regional and global conservation and management measures". ${ }^{33}$

29 Ibid., Article 36(2)-(3).

30 Action in respect of non-cooperating third countries is limited to retorsion. In this respect, EC No. $1005 / 2008$ (n 1), Article $38(8)$ is limited to agreements where a vested right of termination is provided. T Giegerich, 'Retorsion' in R Wolfrum (ed), Max Planck Encyclopedia of Public International Law (Online Ed., Oxford University Press, Oxford, last updated March 2011); PSMA (n 5), Articles 20(3), 23(2).

31 E.g., IPOA-IUU, at paras. 66-70; FAO, Voluntary Guidelines for Catch Documentation Schemes (FAO, Rome, 2017), at para. 5.1.

$32 \operatorname{Hosch}(\mathrm{n} 13)$, at pp. $36-38$.

33 Agreement for the Implementation of the Provisions of the United Nations Convention on the Law of the Sea of 10 December 1982 relating to the Conservation and Management of Straddling Fish Stocks and Highly Migratory Fish Stocks (New York, 4 December 1994, in force 11 December 2001) (UNFSA) 2167 UNTS 3, Article 23(1). Note, the right to take measures had been recognised in previous instruments. 
The UNFSA's non-exhaustive list of discretionary port state measures has been reiterated and broadened by subsequent soft law, notably the International Plan of Action to Prevent, Deter and Eliminate Illegal, Unreported and Unregulated Fishing (IPOA-IUU). ${ }^{34}$ This process has now culminated in the detailed and binding provisions of the PSMA. ${ }^{35}$ In short, contracting parties to the PSMA must regulate the entry and use of ports by foreign vessels. ${ }^{36}$ This includes limiting entry to designated ports, requiring advance notification and denying port entry or use in defined cases. ${ }^{37}$ In exercising their territorial jurisdiction, contracting parties must impose documentation requirements and establish a port state inspection regime. ${ }^{38}$

Port state duties may also apply at the regional level. Several RFMO/As include a provision on port state duties in their constitutive instrument, such as the Convention on the Conservation and Management of Fishery Resources in the South East Atlantic Ocean..$^{39}$ Equally, members may be required to implement port state measures under an applicable CMM, such as the Western and Central Pacific Fisheries Commission's (WCPFC) Minimum Standards for Port State Measures. ${ }^{40}$

An exhaustive discussion of practice is beyond the scope of this article, but at both the global and regional level port state duties are treaty-based obligations. ${ }^{41}$ No port state duty under customary law has yet been established, as is evident in the continual need to impose treaty-based obligations and the lack of sufficiently widespread opinio juris for a customary duty. ${ }^{42}$ If the UNFSA's general port state duty was interpreted as reflecting a customary law

34 IPOA-IUU (n 8) at paras. $5^{2-64}$.

35 PSMA (n 5$)$.

36 Subject to ibid., Articles 3-4, 9(6), 10, 11(2).

37 Ibid., Articles 7-9, 11, 18, Annex A.

$3^{8} \quad$ Ibid., Articles 9(2), 12-14, 17, Annexes B-C.

39 Convention on the Conservation and Management of Fishery Resources in the South East Atlantic Ocean (Windhoek, 20 April 2001, in force 13 April 2003) 2221 UNTS 189, Article 15.

40 WCPFC, Conservation and Management Measure 2017-02 On Minimum Standards for Port State Measures (2017), available at https://www.wcpfc.int/doc/cmm-2017-02/ conservation-and-management-measure-minimum-standards-port-state-measures, accessed 30 October 2018.

41 Regional and Global practice discussed further, AN Honniball, 'Extraterritorial Port State Measures' (Ph.D. Thesis, Utrecht University, 2019), Chapters 3, 5 .

42 E.g., soft law pressures: United Nations General Assembly, 'Resolution 72/72: Sustainable fisheries, including through the 1995 Agreement for the Implementation of the Provisions of the United Nations Convention on the Law of the Sea of 10 December 1982 relating to the Conservation and Management of Straddling Fish Stocks and Highly Migratory Fish Stocks, and related instruments' (A/RES/72/72, 19 January 2018), at paras. 85, 86, urging adoption of port state measures and encouraging ratification of the PSMA. 
obligation, it would arguably be a due diligence obligation comparable to that of a flag state's "to take all necessary measures to ensure compliance and to prevent IUU fishing by fishing vessels flying its flag". ${ }^{33} \mathrm{~A}$ port state would therefore need "to deploy adequate means, to exercise best possible efforts, to do the utmost' to prevent IUU fishing" 44 by foreign fishing vessels visiting its ports.

EU practice with regard to non-cooperating port states (Index Table) demonstrates a conceptualisation of 'port state duties under international law' with broader scope and applicability than that established under treaty law. First, although referring to these generally accepted port state standards, the EU unilaterally extends their applicability beyond contracting parties to the PSMA. Vietnam was criticized for being an important port state that did not ratify the PSMA, nor implement the port state measures therein. ${ }^{45}$ Sierra Leone was noted as not limiting entry to designated ports, ${ }^{46}$ and Comoros had no prior notification procedure for entry into its ports. ${ }^{47}$ The PSMA imposes both these port state duties on its contracting parties. ${ }^{48}$ However, neither Sierra Leone nor Comoros had ratified the PSMA at the date the yellow cards were issued. Indeed, it was suggested by the EU that Comoros, as a developing port state, should ratify the PSMA. ${ }^{49}$

Second, if a port state is important for conservation and management of a particular fishery, the EU will utilise the general UNFSA port state duty as a hook to promote reform. This will be the explicit basis for recommendations to UNFSA contracting parties, but recommendations to UNFSA non-contracting parties are less clear on the exact legal source of the port state's duty under international law. For example, Kiribati, Trinidad and Tobago, Ghana, Thailand and Sri Lanka were described as important port states for a particular region

43 Request for an advisory opinion submitted by the Sub-Regional Fisheries Commission (SRFC), Advisory Opinion [2015] ITLOS 21, ITLOS Rep 2015 4, at paras. 129-136, 148-150; The South China Sea Arbitration (The Republic of Philippines $v$ The People's Republic of China), Award [2016] PCA 2013-19 (Arbitral Tribunal (UNCLOS, Annex VII)), at para. 744.

44 Advisory Opinion-SRFC (n 43), at para. 129 (discussing flag states).

45 Commission Decision 2017/C 364/03 (Index Table), at para. 49.

46 Commission Decision 2016/C 144/o6 (Index Table), at para. 32.

47 Commission Decision 2015/C 324/07 (Index Table), at para. 29.

48 PSMA (n 5), Articles 7-10.

49 Commission Decision 2015/C 324/o7 (Index Table), at para. 62. PSMA (n 5), Articles 3(5), 23. However, Iотс Secretariat, 'Іотс Compliance Report for: Comoros', IOTC-2018-CoC15IRo3, 12 April 2018, available at http://www.iotc.org/sites/default/files/documents/ 2018/04/IOTC-2018-CoC15-CRo3E-Comoros_o.pdf; accessed 30 July 2018, at p. 5, reports no port for foreign vessels. See further, Liberian development and need to meet obligations despite having not ratified the PSMA, Commission Decision 2017/C 169/12 (Index Table), at para. 30 . 
or RFMO/A. ${ }^{50}$ Kiribati, Trinidad and Tobago and Sri Lanka were contracting parties to the UNFSA and therefore failed to fulfil their port state duties to promote the effectiveness of international cmMs. ${ }^{51}$ Ghana and Thailand were not contracting parties to the UNFSA, ${ }^{52}$ but nonetheless should adopt general port state measures to control access or use of ports by foreign vessels..$^{53}$ Port states who are members of an RFMO/A have also been found in violation of regional port state duties. ${ }^{54}$ However, for the Commission's analysis of Vietnam's regulation on landings at port, Vietnam was not party to the regional body in question (CCAMLR), nor to either global instrument establishing treaty-based port state duties (UNFSA, PSMA). ${ }^{55}$

Finally, the EU does expand the content of a port state's duty by reference to soft law or national standards. The non-binding IPOA-IUU and Voluntary Guidelines for Flag State Performance are frequently referred to during the procedure to support the issuance of a yellow card. ${ }^{56}$ In the case of Ghana, the Commission assessed compliance with the advisory port state measures established by the Fisheries Committee for the West Central Gulf of Guinea. ${ }^{57}$

50 Commission Decision 2016/C 144/05 (Index Table), at paras. 18-21, 32 (Kiribati); Commission Decision 2016/C 144/07 (Index Table), at para. 20 (Trinidad and Tobago); Commission Decision 2013/C 346/03 (Index Table), at para. 90 (Ghana); Commission Decision 2015/C 142/06 (Index Table), at paras. 63 (Thailand); Commission Decision 2012/C 354/o1 (Index Table), at paras. 319-322 (Sri Lanka).

51 Commission Decision 2016/C 144/05 (Index Table), at para. 16 (Kiribati); Commission Decision 2016/C 144/07 (Index Table), at para. 17 (Trinidad and Tobago); Commission Decision 2012/C 354/01 (Index Table), at para. 332 (Sri Lanka).

52 Ghana acceded to the UNFSA on 27 January 2017, and Thailand acceded on 28 April 2017. UN, 'Status: UNFSA', available at https://treaties.un.org/pages/ViewDetails.aspx? src $=$ treaty\&mtdsg_no $=x x i-7 \&$ chapter $=21 \& l a n g=e n ;$ accessed 1 August 2018. Both states were recommended to become party to the UNFSA, but this was linked to their status as significant flag states, Commission Decision 2013/C 346/03 (Index Table), at para. 151 (Ghana); Commission Decision 2015/C 142/o6 (Index Table), at para. 85 (Thailand).

Commission Decision 2013/C 346/03 (Index Table), at paras. 88, 92 (Ghana); Commission Decision 2015/C 142/06 (Index Table), at para. 56 (Thailand).

54 Commission Decision 2013/C 346/o3 (Index Table), at para. 136 (Ghana); Commission Decision 2012/C 354/o1 (Index Table), at para. 188 (Guinea).

55 Commission Decision 2017/C 364/03 (Index Table), at paras. 22-27, $5^{2}$.

56 IPOA-IUU (n 8); and FAO, Voluntary Guidelines for Flag State Performance (FAO, Rome, 2015), available at http://www.fao.org/3/a-i4577t.pdf; accessed 30 July 2018. See the Commission going beyond current customary international law; ER van der Marel, 'An Opaque Blacklist: The Lack of Transparency in Identifying Non-Cooperating Countries under the EU IUU Regulation' in L Martin, C Salonidis and C Hioureas (eds), Natural Resources and the Law of the Sea: Exploration, Allocation, Exploitation of Natural Resources in Areas under National Jurisdiction and Beyond (JurisNet, New York, 2017) 237-256, at p. 250.

57 Commission Decision 2013/C 346/03 (Index Table), at paras. 122-123. 
National standards have also featured in the analysis of a port state's duty. Examples include EU requirements for a traceability scheme, ${ }^{58}$ the port state's communication with coastal states, ${ }^{59}$ and the implementation of the EU's catch certification scheme. ${ }^{60}$ Beyond legislative reform the EU does assess whether effective enforcement measures and sufficiently severe sanctions against private persons are implemented by third countries. ${ }^{61}$ Again, although the implementation of port state offences is found in port state practice, it is notably absent from the port state's duties under international law which focus on the denial of port privileges (port entry/use). ${ }^{62}$

\section{The Extent to which Port State Duties Feature in the EU's Identification Practice}

The application of the non-cooperating third-country identification procedure is a unilateral action based on information available to the Commission. ${ }^{63}$ Third countries may cooperate in the process, for example, by providing responses or further information requested. ${ }^{64}$ However, as an actor in international law, ultimately the EU identifies whether, for the purposes of the $I U U$ Regulation, a third country failed to discharge its port state duties. This includes which third countries are first selected and issued with a yellow card. As seen above, it also includes the content of a port state's duty and whether

$5^{8}$ Commission Decision 2016/C 144/05 (Index Table), at paras. 14-16 (Kiribati); Commission Decision 2015/C 324/10 (Index Table), at paras. 48-50 (Chinese Taipei).

59 Commission Decision 2013/C 346/o3 (Index Table), at para. 33 (South Korea).

6o Commission Decision 2014/C 185/02 (Index Table), at paras. 52-53 (PNG). Trans-shipment port state authorities have previously refused to countersign catch certificates, "explaining that there is no obligation to do so", Hosch (n 13) at p. 30.

61 EC No. 1005/2008 (n 1), Articles 31(4), 31(5)(b). Discussions reportedly demonstrated "the key to Taiwan's removal from the yellow card list lies on proper law enforcement and fishermen's strict compliance", Council of Agriculture, Executive Yuan, R.O.C. (COA) (Taiwan), 'Taiwan and EU High-level Meeting on Combating IUU Fishing signals Law Enforcement Crucial to Removal of Yellow Card Status', 11 April 2017, available at https:// eng.coa.gov.tw/theme_data.php?theme=eng_news\&id=490\&print=Y; accessed 30 July 2018.

62 Global instruments, UnfSA (n 33), Article 23(4); PSMA (n 5), Articles 4(1)(b), 18(3). Regional instruments, Convention on the Conservation and Management of High Migratory Fish Stocks in the Western and Central Pacific Ocean (Honolulu 5 September 2000, in force 19 June 2004) 2275 UNTS 43, Article 27(4); CCSBT, 'Resolution for a CCSBT Scheme for Minimum Standards for Inspection in Port' (Twenty-Second Annual Meeting 15 October 2015, in force 1 January 2017), para. 23. See 'residual' jurisdiction, EJ Molenaar, 'Port State Jurisdiction: Toward Comprehensive, Mandatory and Global Coverage' (2007) 38(1-2) Ocean Development \& International Law 225-257, pp. 234-235.

63 EC No. 1005/2008 (n 1), Article 31(2).

64 EC No. 1005/2008 (n 1), Articles 32(1), 32(4), 34(1); e.g., Commission Decision 2017/C 169/12 12 (Index Table), at paras. 4, 21, 39 . 
a third country meets those standards. Finally, a green card will only be issued when the EU (acting through the Council) considers a third country's legislative reform has been sufficient.

Formally, to date third countries have only been listed by the Council (red card: step II) for flag or coastal state failures in combatting IUU fishing. ${ }^{65}$ The closest the EU has come to identifying a non-cooperating third country on the basis of its port state duty is to note in the identification by the Commission (red card: step I) that a third country "appears" to have failed its general UNFSA port state duty. ${ }^{66}$

Nonetheless, the preceding yellow card decisions by the Commission demonstrate a greater consideration and identification of deficiencies in port state jurisdiction than the red cards reflect. ${ }^{67}$ The practice included in the Index Table demonstrates the increasing references and assessment of port state measures in the yellow card decisions of the Commission. Of the 25 states subject to the formal process, Commission Decisions concerning 17 states have included implicit or explicit references to a failure to discharge port state duties. Of the 8 states subject to the formal process without any reference to port state duties, the majority are found in the earliest EU practice. ${ }^{68}$ The clear trend is therefore to include port state duties in the identification procedure, despite the lack of third-country listings on this basis.

Furthermore, the IUU Regulation's catch certification scheme requires prior flag state notification for the purposes of EU imports. ${ }^{69}$ Saint Vincent and the Grenadines, Comoros, Sierra Leone, Trinidad and Tobago and Liberia may all be found in the Index Table despite not applying to be a catch-certification state for the purposes of EU importation. ${ }^{70}$ The EU policy is therefore

65 Flag state: Council Implementing Decision 2014/170/EU (Index Table), at paras. 20 (Belize), 28 (Cambodia), 35 (Guinea); Council Implementing Decision 2015/200 (Index Table), at para. 23 (Sri Lanka); Council Implementing Decision 2017/1332 (Index Table), at para. 20 (Comoros); Council Implementing Decision 2017/1333 (Index Table), at. Para 20 (Saint Vincent and the Grenadines). Coastal state: Council Implementing Decision 2014/170/EU (Index Table), at para. 35 (Guinea).

66 Commission Implementing Decision 2017/918 (Index Table), at paras. 47-48 (Saint Vincent and the Grenadines).

67 E.g., the failure by Sri Lanka to fulfil its UNFSA port state duties identified in a yellow card (n 51$)$ did not feature in the red card (n 65).

68 These are: Belize (2012), Cambodia (2012), Fiji (2012), Togo (2012), Vanuatu (2012), Curaçao (2013), Saint Kitts and Nevis (2014), Tuvalu (2014).

69 EC No. 1005/2008 (n 1), Article 20(1).

70 Commission Implementing Decision 2017/918 (Index Table), at para. 8 (Saint Vincent and the Grenadines); Commission Decision 2015/C 324/07 (Index Table), at para. 10 (Comoros); Commission Decision 2016/C 144/06 (Index Table), at para. 9 (Sierra Leone); Commission Decision 2016/C 144/o7 (Index Table), at para. 9 (Trinidad and Tobago); "It 
to address non-cooperating third countries regardless of any nexus to the EU market. ${ }^{71}$

\section{The Legislative Reform of Third-country Port States Following EU Engagement}

The EU's objective is to stimulate third countries to adopt port state measures equal to, or more stringent than, a port state's duty under international law as interpreted by the EU. ${ }^{72}$ The legislative reform of states found in the Index Table should therefore demonstrate whether the EU procedure has had this impact on non-EU port state measures. The following countries are therefore analysed for legislative reform on port state measures following EU engagement: Chinese Taipei (Taiwan), Comoros, Ghana, Guinea, Kiribati, Papua New Guinea (PNG), The Philippines, Saint Vincent and the Grenadines, Sierra Leone, Solomon Islands, South Korea, Sri Lanka, Thailand, Trinidad and Tobago, and Vietnam.

Liberia and Panama are excluded for different reasons. Liberia's notification on port state obligations was for future landing facilities, not its current practice. ${ }^{73}$ Panama's port state issues concerned inadequate ICCAT reporting. ${ }^{74}$ In both cases, the EU practice did not refer to port state measures that needed to be adopted through legislative reform. Subsequent reform cannot therefore be linked to the EU's non-cooperating identification procedure in a comparable manner to those states listed above. ${ }^{75}$

is largely a problem of the international fleets operating from the port in Trinidad and Tobago", RV Anrooy, FAO fisheries and agriculture officer for the Caribbean, quoted, J Fraser, 'Trinidad and Tobago's IUU fishing yellow card from EU sign of deeper problem', SeafoodSource, 16 August 2017, available at https://www.seafoodsource.com/features/ trinidad-and-tobago-iuu-fishing-yellow-card-from-eu-sign-of-deeper-problem; accessed 15 April 2018; Commission Decision 2017/C 169/12 (Index Table), at para. 9 (Liberia).

71 EC No. 1005/2008 (n 1), at Recital [30], contrasting with CDS protectionist objective, at Recital [9]. Hosch (n 13), at p. 35, as of 1 May 2016, over $42 \%$ of yellow cards issued to third countries with "no established seafood trade to the EU market".

72 Explicit objective, Commission Decision 2017/C 364/03 (Index Table), at para. 44 (Vietnam); Commission Decision 2017/C 169/12 (Index Table), at para. 23 (Liberia).

73 It has reportedly been policy since 2013 to accede to and implement the PSMA (currently unfulfilled); SA Sherif, "The development of fisheries management in Liberia: Vessel Monitoring System (VMs) as enforcement and surveillance tools - national and regional perspectives' (M.Sc., Thesis, World Maritime University, 2014), at pp. 27, 60-63.

74 Commission Decision 2012/C 354/01 (Index Table), at paras. 258, 272.

75 However, see Ministry of Agriculture Development (Panama), 'Executive Decree No. 161 Which establishes the mechanisms for inspections, surveillance and control of 
The legislative reform of third countries following implicit or explicit EU engagement on port state duties demonstrates two key trends. First, generally accepted port state measures found in global and regional instruments have been prescribed with national variations thereof. In meeting the port state's duty under international law, third countries have prescribed a legislative framework to regulate and deny port state privileges (port entry or use). Second, third countries have implemented port state offences with more onerous enforcement measures. Prescribing port state offences is a discretionary exercise of jurisdiction that goes beyond the current port state duties under international law. ${ }^{76}$

\section{Implementation of Port State Measures to Regulate Port Entry or Use}

Port states should regulate the entry and use of port by foreign vessels so as to prevent, deter and eliminate IUU fishing. A port state's duty may be addressed through adopting the minimum standards found in the PSMA. Guinea, ${ }^{77}$ the Philippines, ${ }^{78}$ Sri Lanka $^{79}$ and Thailand ${ }^{80}$ have all adopted a legislative

capture and support fishing operations to the international service Panama flag vessels', 6 June 2013, Article 10, translation available at https://www.segumar.com/wp-content/ uploads/2013/08/Executive-Decree-No.161.pdf; accessed 15 April 2018.

76 See (n 62); E Witbooi, 'Illegal, Unreported and Unregulated Fishing on the High Seas: The Port State Measures Agreement in Context' (2014) 29(2) The International Journal of Marine and Coastal Law 290-320, at pp. 300 (obligatory denial of port privileges), 320 (PSMA omission of further enforcement measures).

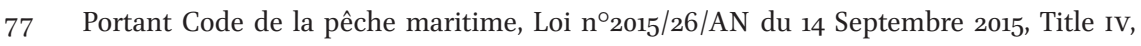
Chapter II, Articles 131-140, and cross-references, e.g., Articles 141-143, unilateral IUU fishing vessel list, denied access (Article 132), available at http://extwprlegsi.fao.org/docs/ pdf/gui158572.pdf; accessed 15 April 2018.

78 The Philippine Fisheries Code of 1998 as amended by Republic Act No. 10654, entitled "An Act to Prevent, Deter and Eliminate Illegal, Unreported and Unregulated Fishing" (2014) Articles 4(73), 42; Rules and Regulations Implementing Republic Act No. 8550, as amended by Republic Act No. 10654 (2015) Department of Agriculture Administrative Order No. 10, Series of 2015, Rules 42.1-42.3, both available at https://www.bfar.da.gov.ph/ BFAR_ANNOUNCEMENT?id=70\#post; accessed 31 July 2018. Denial of entry and other port services may also be an administrative sanction for serious violations, Ibid., Article $135(6)$.

79 Fisheries and Aquatic Resources Act, Act No. 2 of 1996, as amended by Acts until Act No. 2 of 2016 (1996), Articles 61(1)(L) and 61(1)(t), regulation on landing, or the implementation of CMMs including those adopted under PSMA (available in DFAR (n 174)). Implementation of Port State Measures to Prevent, Deter and Eliminate Illegal Unreported and Unregulated Fishing Regulations 2015 (2015) The Gazette of the Democratic Socialist Republic of Sri Lanka Extraordinary, LD B 1/2012/ II, available at http://extwprlegsi.fao.org/ docs/pdf/srl169342.pdf; accessed 31 July 2018.

80 Royal Ordinance on Fisheries B.E. 2558 (2015), as amended by Royal Ordinance on Fisheries (No.2) B.E.2017 (2017), Government Gazette 28 June 2017, Article 95, English 
framework to implement the PSMA. Variations in practice can be more extensive than the PSMA's minimum requirements, such as including $100 \%$ in-port inspection coverage for foreign vessels. ${ }^{81}$ This likely goes beyond a minimum annual inspection level sufficient to achieve the PSMA's objectives. ${ }^{82}$ Equally, national implementation may require further elaboration if a state wishes to clearly demonstrate full compliance with the PSMA. ${ }^{83}$ This includes legislation not addressing IUU fishing beyond the state's coastal state maritime zones (Ghana), ${ }^{84}$ or not as yet including detailed implementation of port state measures (Vietnam). ${ }^{85}$

translations available at http://extwprlegsi.fao.org/docs/pdf/tha159730.pdf; https://www .fisheries.go.th/law/images/PR2558/3-Royal-Ordinance-on-Fisheries-Amendment-No2 .pdf; accessed 30 July 2018. Notification of Ministry of Agriculture and Cooperatives on Advance Data Reporting, and Determining Ports for Non-Thai fishing vessel wishing to enter the Kingdom B.E. 256o (AD 2017), 16 July 2018, unofficial translation available at https://www.wcpfc.int/doc/th-16-july-2018/thailand-port-state-measures-notification; accessed 31 July 2018. Coverage, MFA, 'Press Release: The prosecution of the fishing vessel "Chotchainavee 35" and the rescue missions of the Thai fishing crews on "Chotpattana 51" and "Chotpattana 55"', MFA 1 February 2018, available at http://www.mfa.go.th/main/ en/news3/6886/86308-The-prosecution-of-the-fishing-vessel-\%E2\%80\%9CChotchainav .html; accessed 15 April 2018.

81 Implementation PSMs Regulation (n 79), Articles 8-10 (Sri Lanka). See also the Thai inspection practice since May 2017, concerning all foreign-flagged fishing and carrier vessels wishing to land or trans-ship in-port, Department of Fisheries (Thailand), 'Thailand's Path to Sustainable Fisheries', 28 February 2018, at p. 12, available at http://www4.fisheries .go.th/local/file_document/20180228101142_1_file.pdf; accessed 15 April 2018.

$82 \quad$ PSMA (n 5), Article 12(1).

83 J Swan, Implementation of Port State Measures: Legislative Template, Framework for Procedures, Role of Regional Fisheries, Management Organizations (FAO, Rome, 2016), at pp. $12-17$ for an overview of PSMA provisions requiring implementation through national legislation and/or procedures.

84 Fisheries Act 2002, Act 625, 16 January 2002, as amended, Fisheries (Amendment) Act 2014, Act 880, 9 December 2014, Article 139(3), broad ministerial competence to adopt PSMs. However, Fisheries (Amendment) Regulations, L.I. 2217 of 2015, 19 March 2015, Article 44(b), PSMs are limited to foreign-flagged vessels intending to fish in Ghanaian waters having applied for a foreign fishing licence. Note the coastal state prohibition of foreign fishing vessel entering the fishery waters of Ghana, unless an exception applies, Fisheries Act 2002, Article 61(2). All available at https://www.fcwc-fish.org/regulationspolicies/ghana/category/25-ghana.html; accessed 31 July 2018.

85 Law on Fisheries, Law No. 18/2017/QH14, 21 November 2017, Articles 83 on designated ports and advance notification requirements, 8(5) cooperation in inspection, but not yet including detailed port state inspections, available at http://extwprlegsifao.org/docs/ pdf/vie171855.pdf; accessed 1 August 2018. Pointing to further regulation, ibid., Articles 83(3), 83(8); Prime Minister of Vietnam, 'Directive 45/CT-TTg: On a number of tasks and solutions to remove the warning of the European Commission against illegal, unreported and unregulated fishing (IUU)', 13 December 2017. 
Furthermore, some third countries have prescribed very broad conditions to regulate the access of foreign vessels to ports and port services. These include static vessel conditions which "follow' the ship wherever it is", ${ }^{86}$ such as having driftnets (Kiribati), ${ }^{87}$ but also 'operational' conditions concerning a belief or suspicion of extraterritorial conduct. Thus, grounds to deny port entry include suspected driftnet fishing (Kiribati), ${ }^{88}$ IUU fishing (Thailand, ${ }^{89}$ South Korea) ${ }^{90}$ and any activity in contravention of CMMs ( $\mathrm{PNG},{ }^{91}$ Kiribati).${ }^{92}$ Denial of port services may follow equally broad conditions (PNG), ${ }^{93}$ or demand demonstrable compliance with applicable harvesting laws (Thailand). ${ }^{94}$ Alternatively, legislation may simply allow the addition of any further $a d-h o c$ conditions as seen fit (Kiribati, ${ }^{95}$ Solomon Islands). ${ }^{96}$

Following the example of the EU, some states have adopted a unilateral IUU vessel list (Guinea, ${ }^{97}$ Thailand). ${ }^{98}$ A vessel's RFMO/A IUU vessel listing may

86 H Ringbom, 'Global Problem - Regional Solution? International Law Reflections on an EU CO2 Emissions Trading Scheme for Ships' (2011) 26(4) The International Journal of Marine and Coastal Law 613-641, at pp. 621-623.

87 Fisheries Act 2010, Act No. 6 of 2010, 23 August 2010, as amended Fisheries (Amendment) Act 2015, Act No. 1 of 2015, 16 April 2015, and Fisheries (Amendment) Act 2017, No. 5 of 2017, 14th August 2017, Article 20(1)(b)-(c).

88 Ibid., Articles 2o(1)(a), 3 (includes support).

89 Royal Ordinance on Fisheries (amended) (n 80), Article 94.

90 Distant Waters Fisheries Development Act, Act No. 8626, 3 August 2007, as amended by Acts until Act No 13001, 6 January 2015, Article 14(2)-(4), available at http://extwprlegsi. fao.org/docs/pdf/kor16oo14.pdf; accessed 15 April 2018.

91 Or support; Fisheries Management Act 1998, No. 48 of 1998, as amended, Fisheries Management (Amendment) Act 2015, No. 1 of 2015, Article 63A, available at http://www .fao.org/faolex/results/details/en/c/LEX-FAOC155772; accessed 1 August 2018; reasonable grounds to believe may result in detention or revocation of authorisation to enter.

92 Fisheries Act (amended) (n 87), Article 21(A)(1).

93 Fisheries Management Act (n 91), Articles $63 \mathrm{~A}_{(1)}$ conditional entry, ${ }_{3} \mathrm{~B}(\mathrm{l})(\mathrm{h})-(\mathrm{j})$ subsequent regulations on use; Fisheries Management Regulation 2000, S.I. No. 2 of 2000, as amended Fisheries Management (Amendment) Regulation 2016, S.I. No. 2 of 2016, Article $24 \mathrm{~A}$, available at http://www.fisheries.gov.pg/Portals/o/Fisheries\%2oManagement\%20 \%28Amendment\%29\%20Regulation\%202016.pdf; accessed 1 August 2018.

94 Royal Ordinance on Fisheries (amended) (n 8o), Articles 95-96.

95 Fisheries Act (amended) (n 87), Articles 8(2) (prohibition), 12(2) (licencing for load/unload/transhipment), 12(3)(b) (conditions imposed), 9(a) (discretion over conditions).

96 For those without a fisheries licence for the Solomon Islands (i.e., no connection to the Solomon Islands fisheries), a further written authorisation is required for port entry/use, subject to ad-hoc conditions, Fisheries Management Act 2015, No.2 of 2015, Articles 87(2), 88(1)(a), 89(1), available at http://extwprlegsi.fao.org/docs/pdf/sol153557.pdf; accessed 15 April 2018.

97 Portant Code de la pêche maritime (n 77), Articles 141-143.

98 Royal Ordinance on Fisheries (amended) (n 80), Articles 94, 116-119. 
result in the denial of port entry or services (Solomon Islands). ${ }^{99}$ Alternatively, port entry/use may be limited to RFMo/As Authorised Vessel List vessels, or flag-state authorised vessels (Chinese Taipei). ${ }^{100}$ Vessel listing may also be linked to subsequent port state offences (below). A state's IUU vessel lists may build on regional, sub-regional or global IUU vessel lists (PNG), ${ }^{101}$ or it may even incorporate other national IUU vessel lists (Chinese Taipei). ${ }^{102}$

Indeed, like the EU identification process, all vessels flying the flag of a state not fulfilling its international responsibilities may be denied port entry and use (South Korea). ${ }^{103}$ The use of Sri Lankan ports may be denied to fishing vessels from flag states not party to the Indian Ocean Tuna Commission (IOTC). ${ }^{104}$ Chinese Taipei complements and extends other identification processes, listing and denying port privileges when "the flag State of the fishing vessel is identified as IUU fishing non-cooperating country or is subject to a letter of identification for more than 2 years by other countries, international fisheries organizations, or other regional economic integrated organizations". ${ }^{105}$

\section{Prescription of Port State Offences}

Legislative reform by some third countries reflects several common approaches in prescribing port state offences to address extraterritorial IUU fishing. The

99 Fisheries Management Act (n 96), Article 88(1)(b), not granted authorisation, subject to Article 88(2)-(3) exception.

100 Regulations on the Management and Approval of Foreign Flag Fishing Vessels Entering into Ports of the Republic of China, COA Order No. Nung-yu-tzu 1051338468 20, January 2017, as amended, COA Order No. Nung-yu-tzu 1071334297, 29 May 2018, Article 2(1), available at https://law.coa.gov.tw/GLRSnewsout/EngLawContent.aspx?lan=E\&id=30o; accessed 1 August 2018.

101 Fisheries Management Act (n 91), Article 63B(1)(i).

102 Act for Distant Water Fisheries, Presidential Order Hua-Tsung (1) Yi-Tzu No. 10500079291, 20 July 2016, Article 22(2)(1), available at https://law.coa.gov.tw/GLRSnewsout/EngLaw Content.aspx?id=229; accessed 15 April 2018.

103 Distant Waters Fisheries Development Act (n 90), Articles 14(4), may prevent the entry, departure, and use of ports, 14(3)(4), if inspection reveals IUU fishing, including inspection of vessels "Where the ship has the nationality of any state designated by a foreign government as a state of illegal, unreported, or unregulated fisheries".

104 Implementation PSMs Regulation (n 79), Article 2 (licence for port use mandatory). "Fish landing permits are issued only for foreign fishing boats, the flag States of which are member countries of IOTC and that have no history of engaging in IUU fishing activities" DFAR, 'Sri Lanka National Plan of Action to Prevent, Deter and Eliminate Illegal, Unreported and Unregulated Fishing', 2015 (first published 2013), para. 54, available at http://extwprlegsı. fao.org/docs/pdf/srl161856.pdf; accessed 1 August 2018. It may be in practice, Sri Lanka goes further, prohibiting all landings by foreign vessels for the time being. See moratorium as reported, Ministry of Fisheries and Aquatic Resources (n 16o), at p. 3.

105 Act for Distant Water Fisheries (n 102), Article 22(2)(2). 
three main types of port state offences discussed below are territorialisation via a vessel's subsequent use of port, in-port authorisation or documentary irregularities, and Lacey Act style provisions.

The international law of state jurisdiction mandates that a port state has a sufficient jurisdictional nexus to extraterritorial conduct before it may prescribe and enforce any measures beyond the denial of port privileges. ${ }^{106}$ Nonetheless, prescription of conditions to access port privileges and the prescription of port state offences governed by the international law of state jurisdiction are not mutually exclusive. When a vessel ignores the denial of entry or services a territorial offence can be crafted around the subsequent in-port conduct, irrespective of the grounds for denial or whether the state correctly interpreted the extraterritorial conduct as IUU fishing. When port entry or use is a constituent element of an offence, it is completed in port. The state is then exercising objective territorial jurisdiction. ${ }^{107}$

Thus, some third countries prescribe non-compliance with port state measures discussed above as a serious offence. This includes port entry without the necessary authorisation (Chinese Taipei) ${ }^{108}$ or notification (South Korea). ${ }^{109}$ Territorial conduct would also include the entry of prohibited vessels, such as driftnet vessels (Kiribati). ${ }^{110}$ Refusal to leave port within a reasonable period would also be a territorial offence (Thailand). ${ }^{111}$

106 The American Law Institute, Restatement of the Law Fourth, The Foreign Relations Law of the United States (The American Law Institute, Philadelphia, 2018), at §§ 407-413. E.g., a transfer of jurisdiction; EC No. 1005/2008 (n 1), Article 41(3), cross-referencing Article 11(4); Royal Ordinance on Fisheries (amended) (n 80), Article 8. Prescription of conditions for port entry or use relies on an exceptional domaine réservé-based jurisdiction, resulting in differing legal analysis, Honniball (n 41).

107 C Ryngaert, 'Territorial Jurisdiction over Cross-Frontier Offences: Revisiting a Classic Problem of International Criminal Law' (2009) 9(1) International Criminal Law Review 187-209, at p. 208.

108 Act for Distant Water Fisheries (n 102), Articles 37(1)(1), and 37(3)-(4). Two foreign vessels reportedly fined for not submitting an application; Fisheries Agency Press Release, 'International Linkage - Assurance and Sustainability Press Conference: Results of Taiwan's Work on Combating IUU Fishing', $F A-C O A, 2$ October 2017, available at https:// www.fa.gov.tw/en/Announcement/content.aspx?id=5o\&chk=foo6f8ba-a4ca-4of6-a3bc729 e 79 b14d5c; accessed 30 July 2018.

109 Distant Waters Fisheries Development Act (n 9o), Articles 33(2)(1), 33(4)-(5), ibid., Article 35, fines or confiscation. However, the National Plan only notes referral to flag states, Ministry of Oceans and Fisheries (South Korea), 'National Plan of Action of the Republic of Korea to Prevent, Deter and Eliminate Illegal, Unreported and Unregulated Fishing', August 2014, at p. 25, available at http://www.fao.org/fishery/docs/DOCUMENT/IPOAS/ national/KoreaRep/NPOA_IUU_Korea_Republic.pdf; accessed 1 August 2018.

110 Fisheries Act (amended) (n 87), Article 20(2).

111 Royal Ordinance on Fisheries (amended) (n 8o), Article 96(3). 
As ports are located in the territory of the port state, it may also exercise territorial enforcement jurisdiction. ${ }^{112}$ Enforcement options for the offence of non-compliance with port state measures will therefore include fines and confiscation (Guinea, ${ }^{113} \mathrm{PNG}$ ), ${ }^{114}$ or 'appropriate' follow-up action (Solomon Islands). ${ }^{115}$ For example, a port state can prohibit the port entry of stateless or IUU fishing vessels. ${ }^{116}$ Subsequent port entry in breach of this prohibition can be, for example, subject to confiscation of vessel and catch (Chinese Taipei). ${ }^{117}$ Implementation of these laws is beyond the scope of this article, but it is worth noting proceedings were at least initiated by Thailand for 7 stateless vessels, ${ }^{118}$ and one foreign IUU fishing vessel brought into Thailand. ${ }^{119}$

In the second type of port state offence covered by this article, documentation requirements can reframe extraterritorial conduct as territorial reporting submissions necessary for territorial conduct. When port entry or use is conditional on an authorisation, licence, or documentation, the port state offence of documentation or licencing irregularities would be strictly territorial. For example, the landing of a fisheries catch in selected third countries now requires documentation (Sri Lanka, ${ }^{120}$ Guinea, ${ }^{121}$ Thailand). ${ }^{122}$ Any landings

\footnotetext{
112 The American Law Institute (n 106), § 432.

113 Portant Code de la pêche maritime (n 77), Article 246.

114 Fisheries Management Act (n 91), Articles 63A(7), 63B(2), 58(1)(dd).

115 Fisheries Management Act (n 96), Articles 87(3) and 89(3), fines or imprisonment for non-authorised port entry/use.

116 See, (Chinese Taipei), Act for Distant Water Fisheries (n 102), Articles 22(3), involved in IUU fishing, 22(5), stateless vessels; (Thailand), Royal Ordinance on Fisheries (amended) (n 80), Article 94.

117 Only for stateless vessels; Act for Distant Water Fisheries (n 102), Article 37(6).

118 Royal Ordinance on Fisheries (amended) (n 80), Article 96(3); MFA, 'Press Release: Thailand prosecuted 7 Stateless Fishing Vessels', MFA, 15 February 2018, available at http:// www.mfa.go.th/main/en/news3/6886/86734-Thailand-prosecuted-7-Stateless-FishingVessels.html; accessed 15 April 2018.

119 MFA (n 80). The law of Kiribati also provides for possible detention, Fisheries Act (amended) (n 87), Article $21 \mathrm{~A}(5)$.

120 Maintained logbooks, Implementation PSMs Regulation (n 79), Article 14.

121 Actors must demonstrate the legality of their catch via documentation, Portant Code de la pêche maritime (n 77), Articles $155^{-15}$; lack of certification can result in listing and PSMs (ibid., Article 141(a)).

122 Royal Ordinance on Fisheries (amended) (n 80), Articles 92, 96. See "stringent traceability inspections" by reference to the PSMA and the proposed "Thai Catch Certificate Scheme", MFA, 'Press Release: Thailand Announced the Roadmap towards the IUU-Free Thailand', MFA, 4 April 2018, available at http://www.mfa.go.th/main/en/news3/6886/87958Thailand-Announced-the-Roadmap-towards-the-IUU-Fre.html; accessed 1 August 2018.
} 
undertaken without documentation, or using falsified documents, is a territorial offence (Thailand, ${ }^{123}$ Philippines). ${ }^{124}$

Nonetheless, in exercising their discretion to set the requirements for documentation or licences, states can take account of considerable extraterritorial conduct for valid authorisation or documentation. As an example, Sri Lanka requires an agent' to obtain a further licence to use Sri Lankan ports. ${ }^{125}$ The conditions of that licence may be wholly extraterritorial. For example, the vessel may have to be flagged to an IотC member or use foreign ports in conformity with готс Resolutions and the terms of the PSMA. ${ }^{126}$ Non-compliant extraterritorial conduct is not an offence per se but results in the invalidity of the vessel's licence. ${ }^{127}$ Any subsequent port use is then not under "authority of a licence". ${ }^{128}$ This is a finable offence of violating the regulation's landing provisions. $^{129}$

Finally, the legislation of third countries targeted by the EU identification procedure frequently demonstrates a provision comparable to the USA's Lacey Act. ${ }^{130}$ This provides as follows:

It is unlawful for any person [...] to import, export, transport, sell, receive, acquire, or purchase in interstate or foreign commerce - (a) any fish or wildlife taken, possessed, transported, or sold in violation of any law or regulation of any State or in violation of any foreign law. ${ }^{131}$

\footnotetext{
123 Royal Ordinance on Fisheries (amended) (n 80), Articles 158-159.

124 "[F]ailure to provide a catch report shall be deemed unlawful" Philippine Fisheries Code (n 78) Article 117. Use of any falsified documents covered by the Guinean code is a serious offence, Portant Code de la pêche maritime (n 77), Articles 241(2)(d), 242.

125 Implementation PSMs Regulation (n 79), Article 2. Kiribati licencing (n 82) may also include conditions of extraterritorial conduct, Fisheries Act (amended) (n 87), Articles 12(3) (c), 12(5) (fines).

126 Implementation PSMs Regulation (n 79), Article 5(2); 'Fish Landing Conditions', Schedule III, para. 8.

127 Implementation PSMs Regulation (n 79), Article 5(2).

128 Ibid., Article 2(1).

129 Fisheries and Aquatic Resources Act (n 79) Article 49(5)-(6), the Implementation PSMs Regulation (n 79) being adopted, ibid., Articles 61(L), 61(t).

130 Lacey Act 62 Stat. 687, as amended, codified, 18 United States Code (USC) (2017) § 42-43; Lacey Act Amendments of 1981, Pub. L. 97-79, Nov. 16, 1981, as amended, Pub. L. 108-191, Dec. 19, 2003, Pub. L. 110-234, May 22, 2008, Pub. L. 110-246, June 18, 2008, codified 16 USC (2017) § 3371-3378.

131 Ibid., 18 USC (2017) §3372(a)(2)(a).
} 
The overarching Lacey Act offence of importation is broadly defined to include foreign vessels that enter the jurisdiction with 'illegal' catch aboard.132 Arrival at port while carrying 'illegal' catch is sufficient to demonstrate an import violation. ${ }^{133}$ Transport, or possession of 'illegal' catch provide further options to establish an offence. ${ }^{134}$ In terms of jurisdiction, ${ }^{135}$ two distinct steps must occur. First, the taking, possession, or transport of fish in violation of foreign law ('underlying element'). Second, the subsequent USA import (or bringing into) of those fish by the defendant ('overlying offence'). ${ }^{136}$

For the purposes of this article, the overlying offence is committed by the master of a foreign vessel in port. ${ }^{137}$ Concerning the underlying element, foreign law is broadly defined, and its applicability determined by the USA. ${ }^{138}$ The foreign law violated must be resource-related, whereby one purpose is the protection of wildlife. This requirement is easily met in fisheries conservation and management cases. ${ }^{139}$

By focusing the offence on the subsequent trafficking element, territorial jurisdiction is exercised over a territorial act by the defendant in respect of his/her dealings with 'tainted' property. ${ }^{140}$ This is a distinct act in time and manner from the underlying extraterritorial IUU fishing. ${ }^{141}$ Extraterritorial

132 Ibid., 16 USC (2017) § 3371(b), defining import to include landing or simply bringing into USA jurisdiction.

133 P Ortiz, 'An Overview of the U.S. Lacey Act Amendments of 1981 and a Proposal for a Model Port State Fisheries Enforcement Act', report prepared for the Ministerially Led Task Force on Illegal, Unreported and Unregulated Fishing on the High Seas, Paris, November 2005 (on file with author), at p. 17, noting that even entry in the contiguous zone is sufficient.

134 Transport encapsulates 'moving', Lacey Act (n 130), 16 USC (2017) § 3371(i). Examples, RS Anderson and MD Carraway, 'Current Issues Arising in Lacey Act Prosecutions' (2015) 63(3) The United States Attorneys' Bulletin 3-18, at p. 5.

135 Note, significant limitation of Lacey Act (n 130), 16 USC (2017) § 3377. Discussed, A Cole, M Engelke-Ros and J Galatzan, 'More Than "Just" Paperwork Violations: Combatting IU U Fishing Through Enforcement of Seafood Traceability Schemes' (2015) 63(3) The United States Attorneys' Bulletin $27-38$.

${ }_{13}$ Terminology and the four elements making up the two steps as used; Anderson and Carraway (n 134).

137 Ortiz (n 133), at pp. 14-15, may also include the vessel owner.

138 United States v. McNab (2003) USA Court of Appeals 11th Circuit, 331 F. 3d 1228, at 1241, "regulations and other such legally binding provisions that foreign governments may promulgate $[. .$.$] initial foreign law determination, however, is a question of law for the court".$

$139 U S$ v. McNab (n 138), at 1239; Ortiz (n 133), at pp. 15-16.

140 Providing the 'nexus' to the USA; USA Department of State, 'National Plan of Action of the United States of America to Prevent, Deter and Eliminate Illegal, Unreported and Unregulated Fishing', 2004, at p. 6, available at http://www.nmfs.noaa.gov/ia/iuu/iuu nationalplan.pdf; accessed 10 March 2017.

141 Anderson and Carraway (n 134), at pp. 4-5. 
harvesting conduct may violate foreign law, but it is not itself a violation of US law. "[A] person must do something to wildlife that has already been "taken or possessed' in violations of law".142 Therefore, extraterritorial conduct is not regulated per se but considered as a condition of the fish brought into port. It triggers an offence by the importer. ${ }^{143}$ Therefore, the extraterritorial conduct need not have been committed by the defendant. ${ }^{144}$

In the law of third countries found in the Index Table one will find Lacey Act style provisions. For example, in the port state's territorial jurisdiction it is prohibited to use a vessel for landing, transporting (Solomon Islands, ${ }^{145}$ Kiribati, ${ }^{146}$ PNG), ${ }^{147}$ or simply possessing (Thailand) ${ }^{148}$ illegally harvested fish. This constitutes the overlying offence. Illegally harvested fish are however broadly defined by extraterritorial conduct. This then constitutes the underlying conduct relevant to that offence. Here illegally harvested fish includes that "taken, possessed, transported or sold in contravention of any law or regulation of another State" (Kiribati) ${ }^{149}$ - "or of applicable international conservation and management measures" (Solomon Islands); ;50 - or "taken with the use of a driftnet" (PNG); ${ }^{151}$ - or caught by an IUU-listed vessel (Thailand). ${ }^{152}$

142 Ibid., at p. 4, quoting the US Court of Appeals, 9th Circuit.

143 Hale describing the fish as metaphorically 'glowing', the underlying illegality being the reason why the fish 'glow', C Hale, 'Domestic Fisheries Enforcement' (2015) 63(5) The United States Attorneys' Bulletin 23-28, at pp. 24-25.

144 The "provisions end at the borders of the USA", DS Calley, Market Denial and International Fisheries Regulation: The Targeted and Effective Use of Trade Measures Against the Flag of Convenience Fishing Industry (Koninklijke Brill NV, Leiden, 2011), at p. 7.

145 Fisheries Management Act (n 96), Article 128(1).

146 Fisheries Act (amended) (n 87), Article 28A.

147 Fisheries Management Act (n 91), Article 58(1)(z) (predating EU Engagement).

148 Royal Ordinance on Fisheries (amended) (n 80), Article 61.

149 Fisheries Act (amended) (n 87), Article 28A.

150 Fisheries Management Act (n 96), Articles 128(3)-(4), First Schedule 1, fines apply.

151 Fisheries Management Act (n 91), Article 58(1)(z).

$15^{2}$ Royal Ordinance on Fisheries (amended) (n 80), Article 61, knowledge it was caught through prohibited means. Furthermore, acquired "by a serious infringement under section 114", e.g., use of stateless vessel(s) or "participating in, providing support to or securing essential basics to a fishing vessel undertaking IUU fishing". Section 114 may only apply to Thai nationals extraterritorially, but if the catch is knowingly transferred to a foreign vessel subsequently found in port, its possession would be a finable offence (ibid., Article $142)$. 


\section{The Nexus between Third-country Legislative Reform and the EU's Non-cooperating Third-country Identification Procedure}

This article reviews the EU non-cooperating identification procedure and exhaustively sets out those occasions when the EU has raised a potential failure by third countries to discharge their port state duties, as interpreted by the EU. The legislative reform of third countries following EU engagement was also seen to include considerable port state measures. Third countries have adopted legislative frameworks that empower their authorities to deny port entry or use to foreign vessels suspected of IUU fishing. Their legislative reform also went further in adopting port state offences. These offences, although not in a port state's 'duty' under international law, can be an effective measure to combat IUU fishing. The final question that arises is whether the EU's identification process might be seen as a contributing factor to the subsequent legislative changes abroad.

Eventual listing as a non-cooperating third country will result in actions taken by the Commission and EU Member States against the listed third country. For example, third countries will have had to undertake legislative reform to, in part, avoid losing access to the EU's ports and markets. In order to establish a nexus, if any, this article will primarily rely on official documents and state press releases by the third-country minister or ministry responsible for fisheries which provide prima facie evidence for such a link. These sources can provide evidence of policy preferences underlying state practice. They cannot, however, be taken as exhaustive or absolute. Where necessary, media reports provide supplementary material to demonstrate the effects a loss of EU port and market access would have on states found in the Index Table.

The port state's duty to deny port privileges to IUU fishing vessels should first be distinguished from the prescription of port state offences. The objective of the non-cooperating identification procedure, when applied to port states, is to ensure port states fulfil their duties under international law. Although port state offences have been prescribed after EU engagement, they are not as yet an explicit objective of the non-cooperating identification procedure. This is because only a framework for the denial of port privileges to IUU fishing vessels constitutes the port state's duty under international law. Thus, any nexus here is therefore limited to third countries using the opportunity that legislative reform presents to also exercise residual port state jurisdiction.

This is confirmed by further documentation describing what the EU is requesting from third countries. Not only do Commission Decisions refer to global instruments to give content to a port state's duty, but so too can the Action Plans the EU has developed for third countries. An unpublished Action Plan 
accompanies the notice to a third country and it sets out the suggested actions necessary to "rectify the identified shortcomings". 153 Actions to implement port state duties focus on the implementation of port state measures found in the PSMA and not the prescription of port state offences. Ghana, the Philippines and PNG were requested to 'consider' the port state duties found in the UNFSA and PSMA, and their compliance therewith. ${ }^{154}$ Sri Lanka was requested to fully implement the PSMA, despite the fact the PSMA had yet to enter into force. ${ }^{155}$ More specifically, the Commission may recommend the adoption of a framework for port state inspection. This can be in general, ${ }^{156}$ or as part of their regional port state duties. ${ }^{157}$ These states have since implemented port state measures to regulate port entry and use. Ghana and the Philippines also ratified the PSMA. ${ }^{158}$ Their EU pre-identifications or listing were revoked following this reform (Index Table, column 6).

Of all of the actions the EU and EU Member States can impose, the threat of port or market state measures are amongst the most powerful incentives. ${ }^{159}$ This is evident in the statements made by governmental representatives from those third countries found in the Index Table. The listing of Sri Lanka as a

153 Commission Implementing Decision 2017/918 (Index Table), at paras. 13-18 (Saint Vincent and the Grenadines); in general, EC No. 1005/2008 (n 1), Article 32(1)-(2).

154 Commission, Ghana Action Plan (on file with author); Philippines Action Plan (on file with author) and PNG Action Plan (on file with author).

155 Commission, Sri Lanka Action Plan (on file with author), having previously acceded 20 Jan 2011. FAO, 'Status: Agreement on Port State Measures to Prevent, Deter and Eliminate Illegal, Unreported and Unregulated Fishing', 25 September 2018, available at http://www .fao.org/fileadmin/user_upload/legal/docs/o37s-e.pdf; accessed 30 July 2018.

156 Philippines Action Plan (n 154); PNG Action Plan (n 154); Sri Lanka Action Plan (n 155).

157 Ghana Action Plan (n 154), ICCAT PSMs; PNG Action Plan (n 154), wCPFC CMMs (not explicitly the PSMs).

$15^{8}$ FAO (n 155), Ghana (November 2016) and the Philippines (May 2018). Vietnam is also joining the PSMA following EU nudges during the process. HTra, "The Vietnamese Government has agreed to accede to the Agreement on Port State Measure (PSMA) to prevent, deter and eliminate Illegal, Unreported and Unregulated Fishing (IUU Fishing)', Ministry of Agriculture and Rural Development, 12 July 2018, available at https://tongcucthuysan.gov. vn/en-us/vietnam-fisheries/doc-tin/o11019/2018-07-20/the-vietnamese-government-hasagreed-to-accede-to-the-agreement-on-port-state-measure-psma-to-prevent-deter-andeliminate-illegal-unreported-and-unregulated-fishing-iuu-fishing; accessed 1 August 2018. Prime Minister of Vietnam, 'Decision No 78/QĐ-TTg on national plan of action to prevent, deter and eliminate illegal, unreported and unregulated fishing up to 2025', 16 January 2018, at p. 4, join by 2020, available at http://seafood.vasep.com.vn/pic/files/qd-78_pheduyet-ke-hoach-npoa-iuu-eng-revised-by-phuong_(16-3-2018-852).pdf; accessed 1 August 2018.

159 Note, other actions not discussed may be equally influential; EC No. 1005/2008 (n 1), Article 38 . 
non-cooperating third country was said to have "brought about drastic consequences affecting the livelihood of nearly 2.6 million people and [...] trade loss due to the ban in 2015 [...] estimated to be of 51 Million Euros". ${ }^{160}$ The Solomon Islands Prime Minister recognised the "EU's right to decide which fish it allows to be imported into its market", but equally, that access was "vital" to the Islands' economy. ${ }^{161}$ The Director-General of the Pacific Islands Forum Fisheries Agency suggested "virtually all their [Solomon Islands] fisheries exports were going to Europe". ${ }^{162}$ Any ban on fisheries exports to the EU would be "catastrophic". 163 The Solomon Islands are said to have had little ability to develop alternative markets in the pre-identification period and would have suffered from reputational damage following EU measures. ${ }^{164}$ It may therefore be that little choice exists but to adopt legislation in line with a port state's duty under international law as interpreted by the EU. ${ }^{165}$

Furthermore, third countries are keen to demonstrate subsequent compliance so as to avoid any EU listing decision. Ghanaian legislation was passed, in part, to implement IUU fishing-related obligations and "address EU issues".166 Chinese Taipei's legislative reform was explicitly referred to as part of its strategy to address and lift the EU's yellow card. ${ }^{167}$ The yellow card issued to the

160 Ministry of Fisheries and Aquatic Resources (Sri Lanka), 'Statement on the Recent Developments in Sri Lanka's National Fisheries Governance Policy by Mrs. Mangalika Adikari, Secretary of the Ministry of Fisheries \& Aquatic Resources Development of the Government of Sri Lanka, at the Press Conference in Brussels on 27/04/2016', on file with author, at p. 1 .

161 Tri Marine Group, 'Solomon Islands Prime Minister Announces Supports for New Fisheries Act', 3 February 2015, available at http://www.trimarinegroup.com/news/press/ Trimarine_Announcement_020315.html; accessed 15 April 2018.

$162 A B C$ News, 'Solomons, PNG and Tuvalu Tuna Industries Warned to Comply with Regulations', 3 February 2015, available at http://www.abc.net.au/news/2015-02-03/tunaindustries-in-solomon-islands2c-png-and-tuvalu-warned-to-/6066732; accessed 15 April 2018.

163 Ibid.

164 Ibid.

165 A red card for Chinese Taipei is estimated at yearly losses of US\$243.6 million, Y Sumin and E Kao, 'EU's decision on Taiwan fisheries 'yellow card' expected in April' Focus Taiwan, 21 March 2018, available at http://focustaiwan.tw/news/aeco/201803210032.aspx; accessed 30 July 2018.

166 Ministry of Fisheries and Aquaculture Development (MOFAD) (Ghana), 'Medium Term Expenditure Framework (MTEF) For 2016-2018: Programme-Based Budget Estimates' (2016), at p. 4, available at https://www.mofep.gov.gh/sites/default/files/ pbb-estimates/2016/2016-PBB-16-MOFAD.pdf; accessed 15 April 2018. See also, Vietnam, Directive $45 /$ CT-TTg (n 85).

167 COA, 'Announcement of the First Wave of Penalties on Violations relating to Illegal Fishing Activities for Combating IUU Fishing and ensuring Sustainability of Fisheries Resources', 
Philippines raised awareness of potential EU trade measures which would, as described by the chairperson of the Senate Committee on Agriculture and Food, represent a serious threat to the fishing sector. ${ }^{168}$ Consequently, reforms were adopted. ${ }^{169}$

More broadly, Thailand was initially disappointed by the yellow card, ${ }^{170}$ but "has worked closely in cooperation with the EU [...] to fulfil Thailand's responsibilities as [...] port state". ${ }^{171}$ Similarly, the international port state responsibilities of PNG were implemented after legislative "shortfalls" were said to have been brought to its attention by the EU process. ${ }^{172}$

The most persuasive nexus cases are where documentation accompanying the legislation explicitly or implicitly refers to the EU's identification procedure. A Committee Report accompanying the Solomon Islands' legislation describes how the reforms were quickly introduced to Parliament. This quick introduction of legislation was to ensure the Solomon Islands did not lose access to the EU market and with the expectation that it would be sufficient to fulfil the "European Union fisheries standards". ${ }^{173}$ The Sri Lankan compendium of reform was also "distributed as a part of the road map to revoke the EU fish

15 August 2017, available at https://eng.coa.gov.tw/theme_data.php?theme=eng_ news\&id=500\&print=Y; accessed 30 July 2018. See further, "complying with foreign-market demands [i.e. EU and USA]”, COA, 'Taiwan Signed Fisheries Cooperation Agreements with Tuvalu and Nauru', 19 May 2016, available at https://eng.coa.gov.tw/theme_data .php?theme=eng_news\&id=453\&print=Y; accessed 30 July 2018.

168 M Ramos-Araneta, 'Philippines resumes fish supply to European Union' Manila Standard, 2 May 2015, available at http://manilastandardtoday.com/news/-main-stories/176178/ philippines-resumes-fish-supply-to-european-union.html; accessed 1 August 2018.

169 Ibid.

170 Ministry of Foreign Affairs of the Kingdom of Thailand (MFA), 'Press Releases: Thailand Disappointed with the European Union's Decision to Issue a Yellow Card', MFA 21 April 2015, available at http://www.mfa.go.th/main/en/media-center/14/55710-ThailandDisappointed-with-the-European-Union\%E2\%80\%99s-De.html; accessed 15 April 2018.

171 Department of Fisheries (Thailand) (n 81), at p.14.

172 National Fisheries Agency (PNG), 'PNG and the Fight Against IUU Fishing', 1 October 2015, at pp. 3, 5, available at http://www.fisheries.gov.pg/Portals/o/PNG\%20NFA\%2oIUU\%20 Comms\%2odoc\%20-high\%2ores-\%2ofinal\%20-version\%2ofor\%2oprinter\%201-10-15_1 .pdf; accessed 15 April 2018; I Kireeva, "The PNG Catch Documentation Scheme National Plan of Action' in ACPFish II, Technical Report: Technical Assistance on Trade Facilitation and Standards for Papua New Guinea, September 2013, at p. 20, available at http:// www.fisheries.gov.pg/Portals/o/PNG\%2oCatch\%2oDocumentation\%2oScheme\%20 National\%2oAction\%2oPlan.pdf; accessed 15 April 2018.

173 National Parliament of Solomon Islands Bills and Legislative Committee, 'Report on the Fisheries Management Bill 2015', NP-Paper No.7/2015, 22 April 2012, available at http:// www.parliament.gov.sb/files/committees/bills\&legislationcommittee/2015/Report\%20 on\%2othe\%2oFisheries\%2oManagement\%20Bill\%202015.pdf; accessed 15 April 2018. 
Export Ban-2015". ${ }^{174}$ Finally, an explanatory memorandum accompanying the latest amendments to the law of Kiribati notes that it will "seek to address issues raised by the European Commission" yellow card. ${ }^{175}$

However, it cannot be expected that the identification procedure will always have an influence on third-country legislation. ${ }^{176}$ Saint Vincent and the Grenadines, Comoros, Sierra Leone, and Trinidad and Tobago may all be found in the Index Table. Yet, these third countries have not adopted sufficient legislative reform to discharge their port state duties. ${ }^{177}$ They therefore remain subject to yellow or red cards.

Finally, the EU practice discussed in this article may only be one causal factor for the legislative reform of third-country port states. The EU's identification process might be seen as a contributing factor, but it is important to note the impact of other factors. Other markets or states may have taken measures to incentivise legislative reform. ${ }^{178}$ For example, South Korean legislation may be partially attributed to the EU yellow card. ${ }^{179}$ However, South Korea was also designated under the USA identification and certification scheme for flag state issues. ${ }^{180}$ It may also be the case that states are implementing port state

174 Also explicitly identifying the requirements of the IUU Regulation; Department of Fisheries and Aquatic Resources (DFAR) (Sri Lanka), 'The Compendium of High Seas Fishing Legislations in Sri Lanka', February 2016 (Updated on March 2016), at pp. 4-5, available at http://fisheriesdept.gov.lk/v3/wp-content/uploads/2016/o8/compendium-ofFisheries-act-2016.pdf; accessed 15 April 2018.

175 Fisheries (Amendment) Act 2017, No. 5 of 2017, Explanatory Memorandum, available at http://extwprlegsı.fao.org/docs/pdf/kir177396.pdf; accessed 31 July 2018.

176 An objective thereof, Commission Press Release, IP/17/4064 (n 1).

177 No reform since decision, Commission Implementing Decision 2017/889 (Index Table), at para. 68 (Comoros). Draft Fisheries Management Bill (2015) reportedly underway, Fraser (n 7o) (Trinidad and Tobago). Saint Vincent and the Grenadines became a PSMA contracting party following its yellow card (June 2016), as did Sierra Leone (September 2018), FAO (n 155).

178 Note, EU Member States can also take measures to reject or suspend consignments when concerns of IUU fisheries products contaminating the EU supply chain arise. See practice of the UK and Spain concerning fisheries imports from Ghana which predate the issuance of a yellow card; R Ford, 'Tuna Imports Held Following Warnings of "Illegal Fishing", The Grocer, 20 April 2013, available at http://www.thegrocer.co.uk/buying-and-supplying/ categories/fresh/tuna-imports-held-following-warnings-of-illegal-fishing/238499.article; accessed 1 March 2017.

179 J Park, 'Korea's Fisheries Sector Assessment', $W W W$-Korea, January 2016, at p. 13, available at http://awsassets.wwfkr.panda.org/downloads/kfr_2016_eng_compressed.pdf; accessed 15 April 2018.

180 High Seas Driftnet Fisheries Enforcement Act, Pub. L. 102-582, Nov. 2, 1992, 106 Stat. 4901; Pub. L. 109-479, Jan. 12, 2007, 120 Stat. 3632; Pub. L. 114-81, Nov. 5, 2015, 129 Stat. 656, and High Seas Driftnet Fishing Moratorium Protection Act Pub. L. 104-43, 3 November 1995, as 
measures to meet their treaty-based obligations. This can include obligations assumed under global instruments, such as the UNFSA, ${ }^{181}$ or under regional instruments to which they are a contracting party. ${ }^{182}$

\section{Conclusion}

This article analysed the implementation and influence of the EU's noncooperating third-country identification procedure through a case study on port state duties. It introduced the context of the procedure in the EU's IUU Regulation and how it operates.

A port state's duty under international law will consist of treaty-based obligations to regulate the entry and use of ports by foreign vessels so as to prevent, deter and eliminate IUU fishing. These may be found in global or regional instruments to which a state is party. However, for the purposes of applying the IUU Regulation, the EU's non-cooperating identification procedure uses a broader interpretation of port state duties. The content of such a duty may be taken from global and regional instruments. Its applicability is not, however, limited to contracting parties. For UNFSA contracting parties, other instruments are also used to elaborate which port state measures should be implemented to fulfil the general duty contained therein. Soft law and EU standards may also be used in the analysis of a third country's port state measures. Finally, third countries may be urged to ratify legally binding instruments containing port state duties, notably the PSMA.

No third country has been listed by the Council on the basis of a failure to fulfil its port state duties. Nonetheless, the practice in the Index Table, and its discussion above, demonstrate the extent to which the need for port state measures has been pushed by the Commission during earlier yellow and red card stages. No link between a third country and the EU's market is necessary. A third country's port state duties are now being consistently discussed in

added Pub. L. 109-479, Jan. 12, 2007, 120 Stat. 3630; amended Pub. L. 111-348, Jan. 4, 2011, 124 Stat. 3669; Pub. L. 114-81, Nov. 5, 2015, 129 Stat. 654, 655; Pub. L. 114-327, Dec. 16, 2016, 130 Stat. 1995, codified, 16 USC (2017) §§ 1826-1826k.

181 Taking into account port state obligations under the UNFSA: MOFAD, 'Fisheries Management Plan of Ghana: A National Policy for the Management of the Marine Fisheries Sector 2015-2019', at pp.5, 38, available at http://extwprlegsi.fao.org/docs/pdf/ gha160291.pdf; accessed 15 April 2018.

182 "Sri Lanka has furthermore steadily improved its compliance with Regional Fisheries Management Organisations (RFMO) recommendations and resolutions, such as port state control measures", Commission Implementing Decision 2017/1949 (Index Table), at para. 5 . 
Commission Decisions. This suggests they will remain a staple of future formal third-country non-cooperation procedures.

Looking to the future, the differences in content between the published Commission Decisions and the Commission Action Plans does raise issues of procedural transparency. The Action Plans are to suggest actions that will rectify shortcomings identified in the Commission Decisions. Yet, as can be witnessed in the formal processes for Fiji and Vanuatu, the Commission Decisions do not always fully reflect what was subsequently suggested. Fiji was given a yellow card for concerns over the control Fiji exercised as a flag state and state of nationality. ${ }^{183}$ Yet the Fiji Action Plan also requested Fiji to fulfil its port state obligations in line with the UNFSA. ${ }^{184}$ The yellow card issued to Vanuatu also did not mention port state failures. ${ }^{185}$ Yet, in the Vanuatu Action Plan one will find requests to comply with its port state duty "in line with" the UNFSA. ${ }^{186}$ Vanuatu was a signatory to the UNFSA but had yet to ratify the treaty. ${ }^{187}$

For third countries, the exercise of prescription and enforcement over subjects within their jurisdiction remains an intimate right of states, defining sovereignty. Yet, the response of third countries to the pressures of the EU listing process demonstrates, by and large, the extraterritorial effects intended and at least in the statute books - achieved, is striking. ${ }^{188} \mathrm{EU}$ practice does appear to be one of the contributing factors which may incentivise a state to regulate the entry and use of port by foreign vessels. Prescribing port state measures and accepting a port state duty to combat IUU fishing are necessary to enjoy continued access to EU ports and the EU market.

The demonstrable successes of this mechanism are vital for the EU's oceans policy in general. The Commission's 2016 agenda for the future of our oceans highlights the experiences of the IUU Regulation as evidence to conclude the

\footnotetext{
183 Commission Decision 2012/C 354/01 (Index Table), at paras. 111-141.

184 Fiji Action Plan (on file with author).

185 Commission Decision 2012/C 354/01 (Index Table), at paras. 384-438.

186 Vanuatu Action Plan (on file with author).

187 Ratified 15 March 2018, UN (n 52). Vanuatu subsequently acceded to PSMA, 6 May 2016, FAO (n 155).

188 However, see Sierra Leonne Parliamentary discussion of PSMA; "one of the problems, we are always facing in this country is implementation. The question one would like to ask is that are we going to ensure that this Agreement is implemented as intended? Implementation is the most important aspect of any legislation", Parliament (Sierra Leone), 'First Meeting of the Fifth Session of the Fourth Parliament of the Second Republic of Sierra Leone, Proceedings of the Sitting of the House Held Thursday, 1st June, 2017' (2017) I (28) Official Hansard Report, available at http://www.parliament.gov.sl/dnn5/ Portals/o/HANSARDS/1st\%2oJune\%202017.pdf; accessed 15 April 2018, at p. 16.
} 
"EU is well placed to shape international ocean governance". ${ }^{189}$ As long as access to EU markets and ports remains sufficiently necessary for third countries, this remains true. The most difficult element to achieve and demonstrate would be a third country's 'mind-set change'. One could however tentatively note that several third countries have continued to implement port state duties after receiving a green card. Examples include acceding to the PSMA, ${ }^{190}$ and implementing its provisions into national law. ${ }^{191}$

Finally, many third countries have taken the opportunity to go beyond EU practice and their port state duties by prescribing port state offences. These are subject to more onerous enforcement measures than denial of entry or use. The jurisdictional nexus relied on for prescription is best seen as a broad application of objective territorial jurisdiction. ${ }^{192}$ Indeed, this would arguably fall within an interpretive methodology that has been labelled 'territorial extension'. ${ }^{193}$ This demonstrates the applicability of territorial extension in numerous jurisdictions beyond the EU. The formalistic interpretation methodology of territorial extension focuses on the territorial element of prescription as opposed to the wider extraterritorial issues in its application. The regulation of relatively minor territorial elements can therefore provide the jurisdictional basis for increasingly wide port state practice that addresses extraterritorial IUU fishing. ${ }^{194}$ The EU may have taken the global leadership in prescribing port state measures in 2008. It is, however, within the more recent practice of third countries that we find the expansions of prescribing port state offences with more onerous enforcement measures to be applicable.

189 Commission, 'International Ocean Governance: An Agenda for the Future of Our Oceans' (Joint Communication to The European Parliament, The Council, The European Economic and Social Committee and The Committee of The Regions), JoIN (2016) 49 final 4, 10 November 2016, at p. 4 .

190 Philippines' PSMA accession, 26 May 2018 (green carded in 2015); FAO (n 155).

191 Panama designated ports: Resolución ADM/ARAP No.034 Por la cual se establecen los puertos de entrada autorizados a buques de pesca y de apoyo a la pesca de pabellón extranjero en la República de Panamá y se dictan otras disposiciones, 28433 Gaceta Oficial Digital 27 miércoles 27 de diciembre de 2017 25-28, 21 December 2017, available at http:// extwprlegsi.fao.org/docs/pdf/pan175373.pdf, accessed 4 December 2018.

192 The American Law Institute (n 106), § 408.

193 J Scott, 'Extraterritoriality and Territorial Extension in EU Law' (2014) 62(1) The American Journal of Comparative Law 87-126, at pp. 96-98, (air)ports, 121-122, interventions; J Scott, 'The New EU "Extraterritoriality"' (2014) 51(5) Common Market Law Review 1343-1380, at p. 1355 .

194 Note, the author only applies this approach in respect of port state offences which fall under the international law of state jurisdiction, Honniball (n 41). 


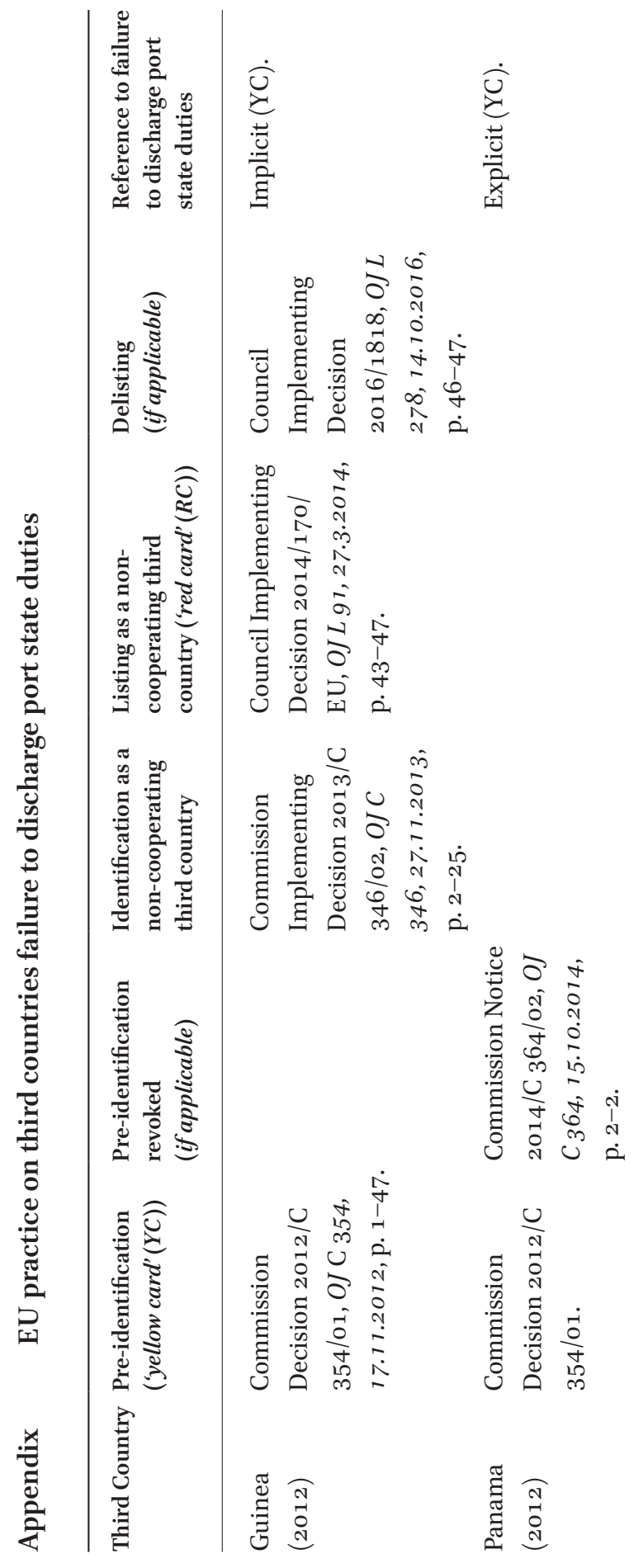




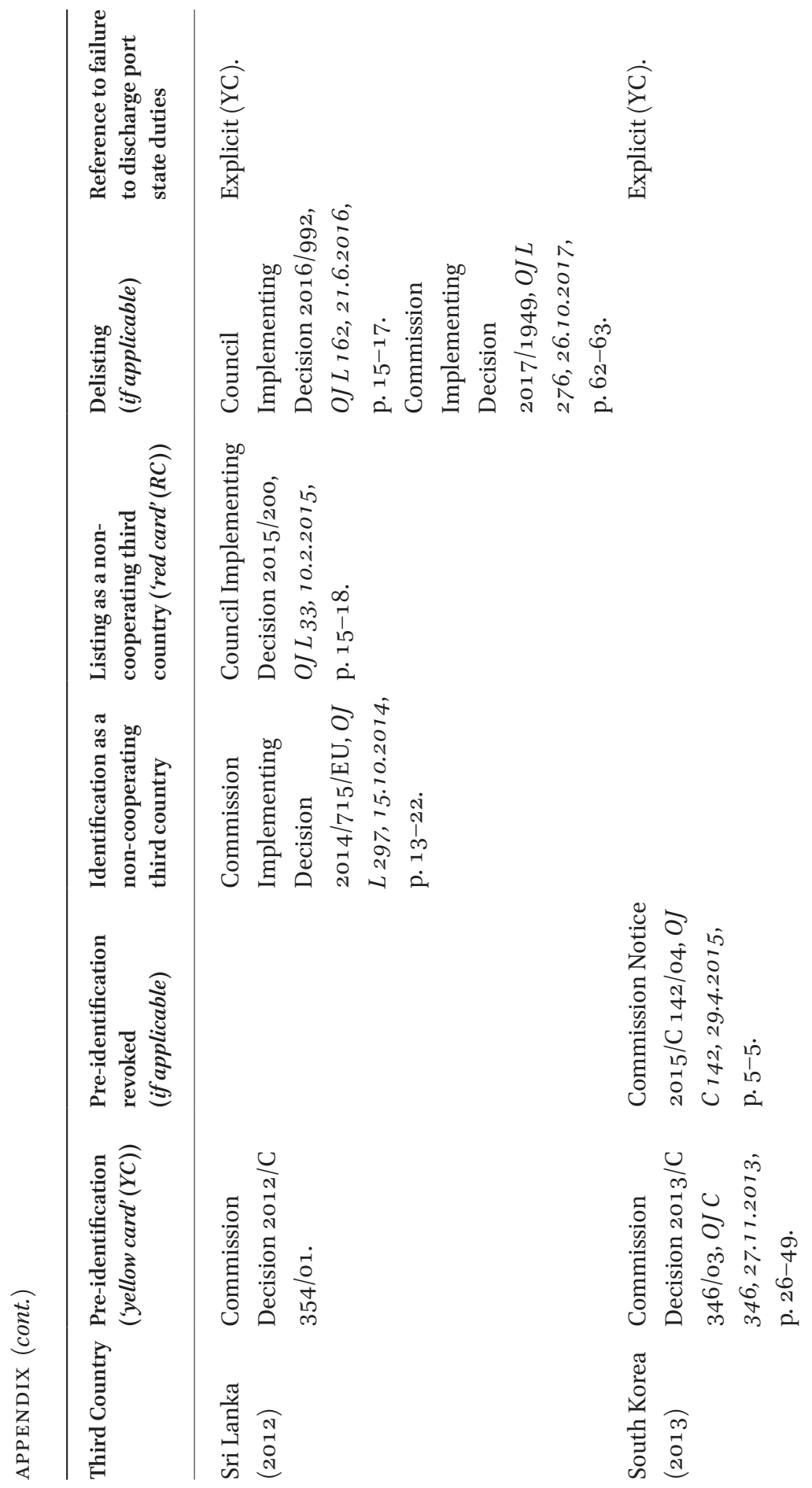




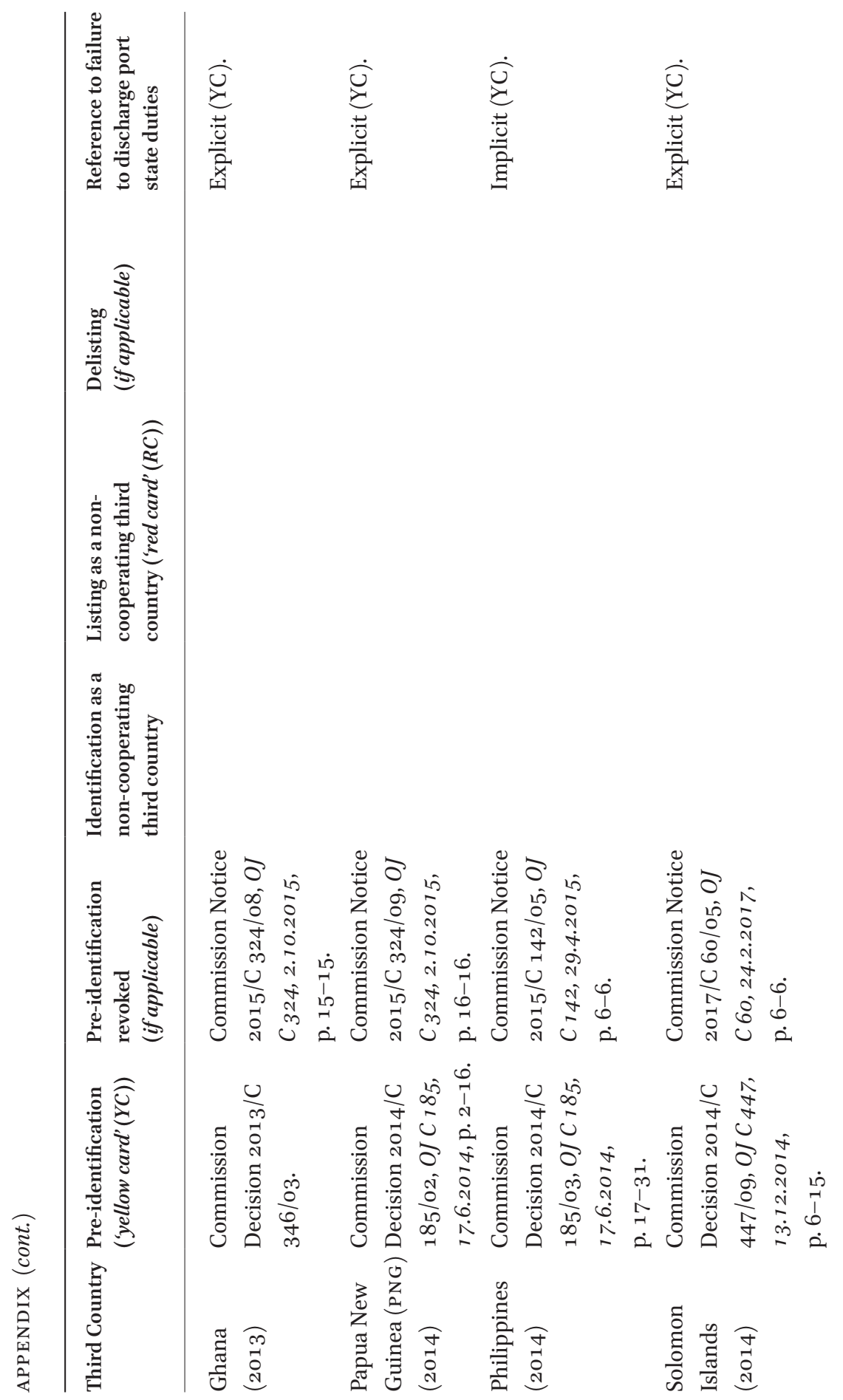




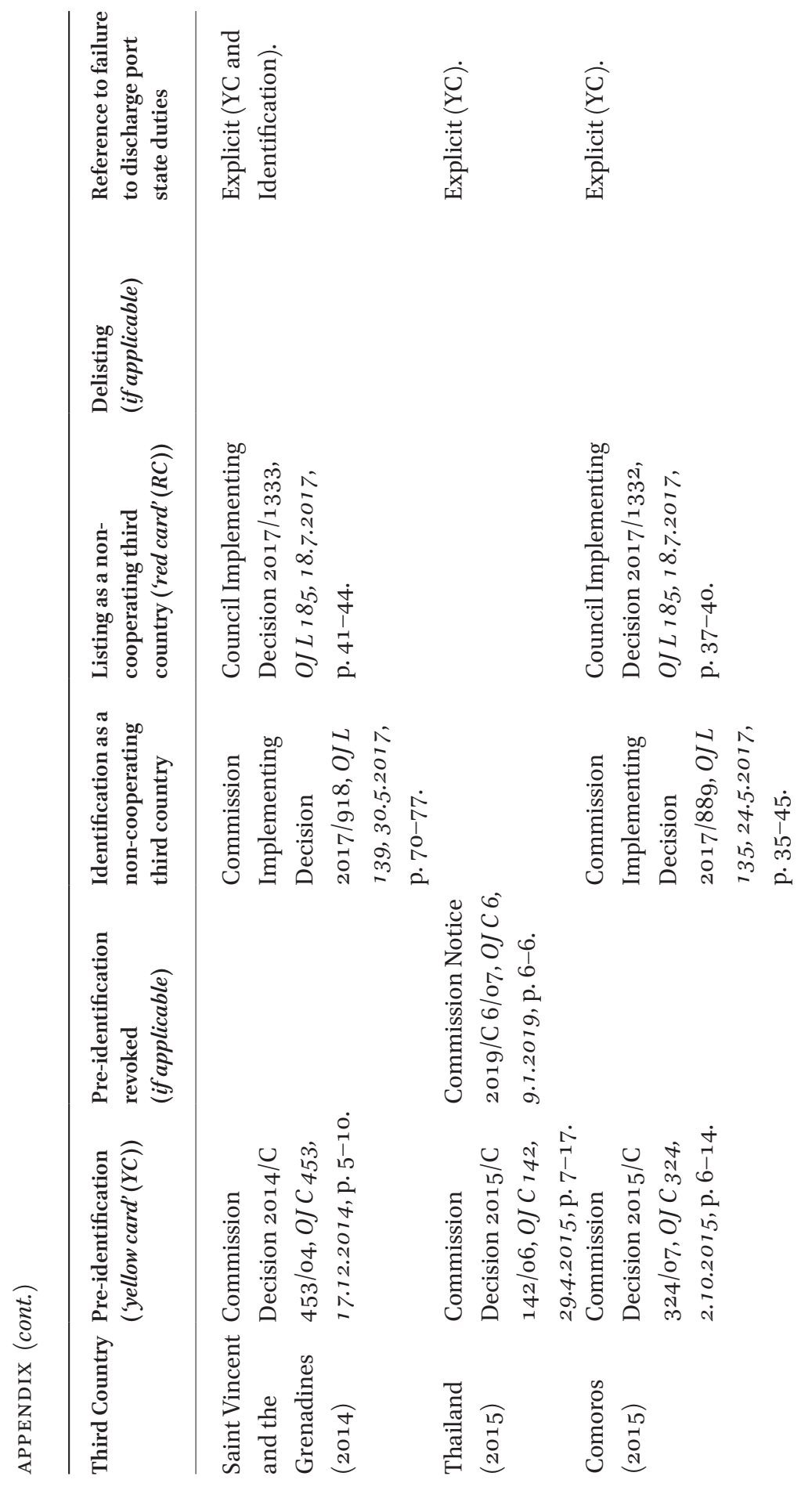




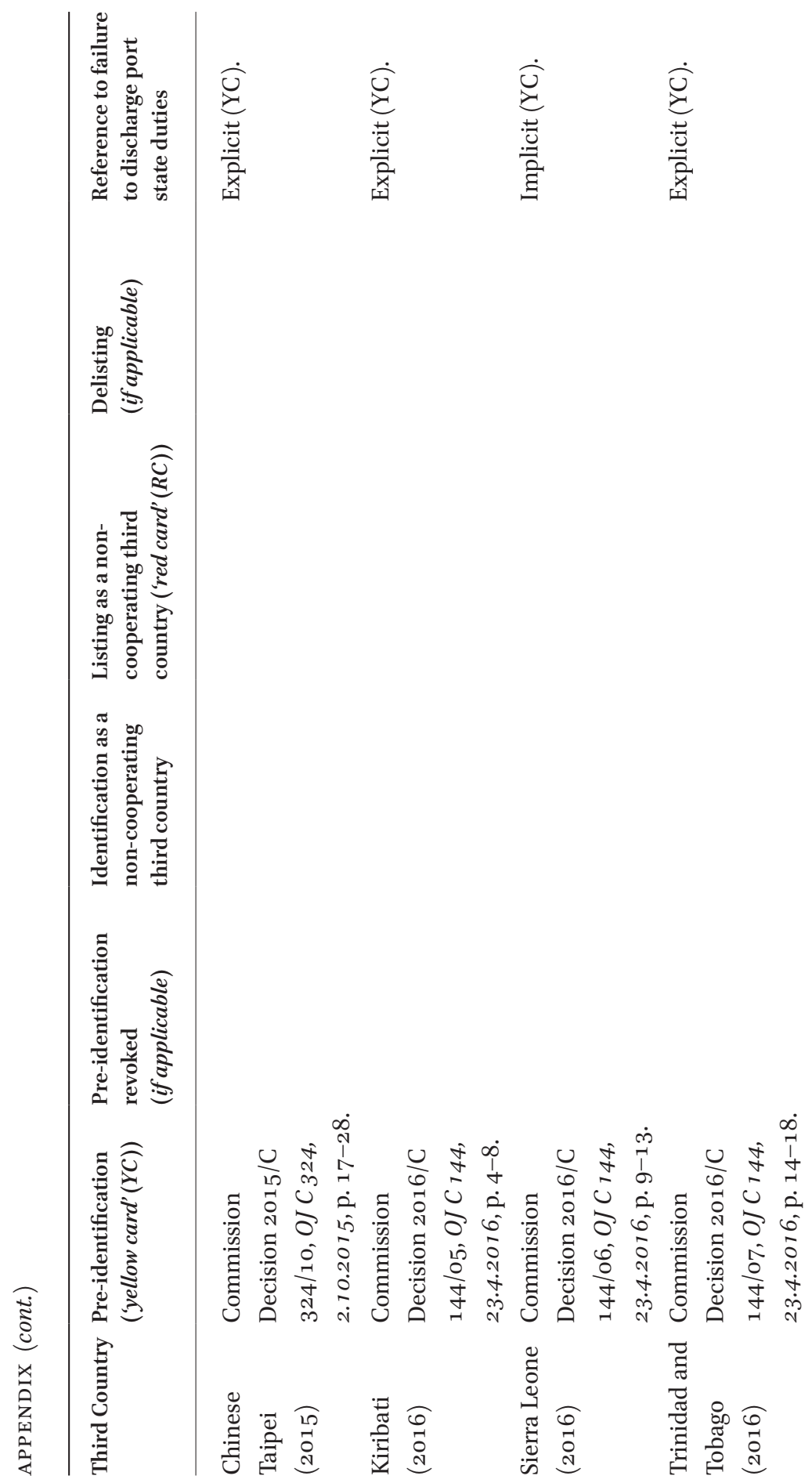




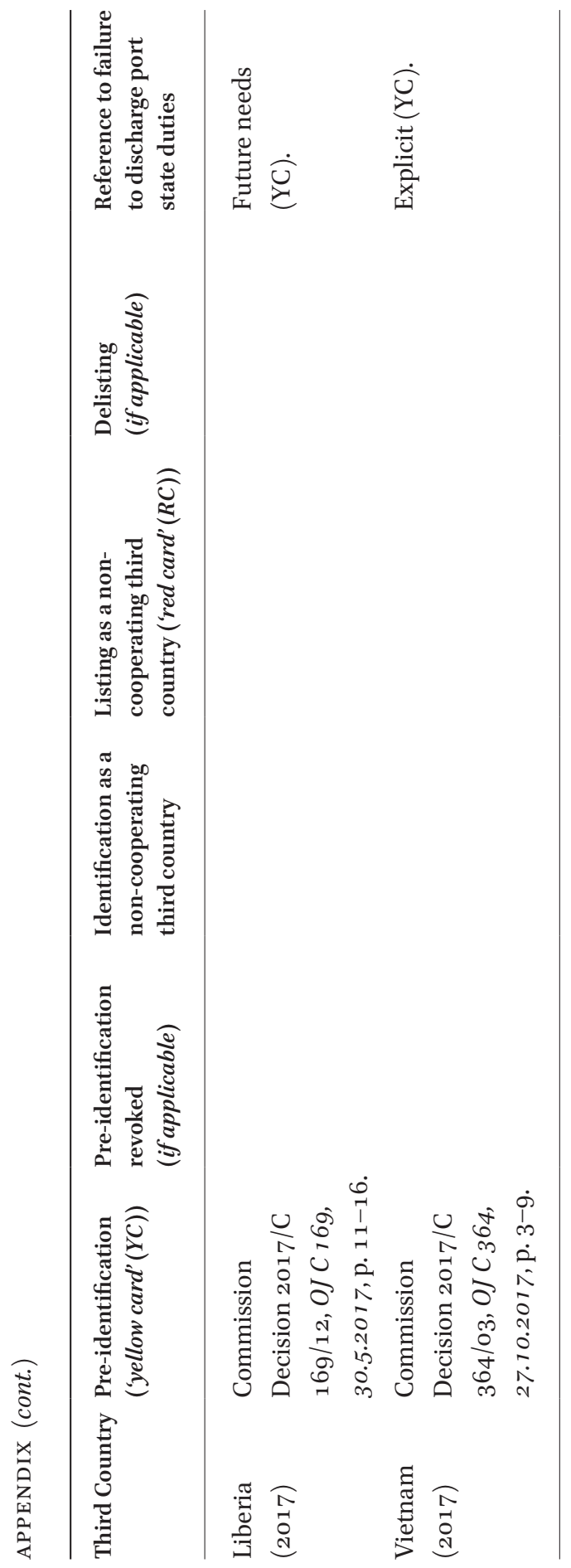

